\title{
Wnt signaling in C. elegans *
}

\author{
Hitoshi Sawa ${ }^{1 \S}$ and Hendrik C. Korswagen ${ }^{2 \S}$ \\ ${ }^{1}$ Multicellular Organization Laboratory, National Institute of Genetics, 1111 Yata, Mishima, \\ 411-8540 Japan. \\ ${ }^{2}$ Hubrecht Institute, Royal Netherlands Academy of Arts and Sciences and University Medical \\ Center Utrecht, Uppsalalaan 8, 3584 CT, Utrecht, The Netherlands.
}

\section{Table of Contents}

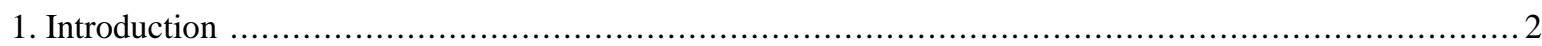

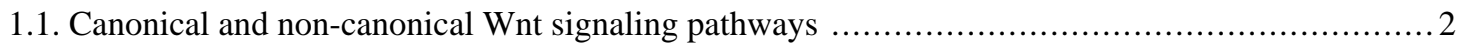

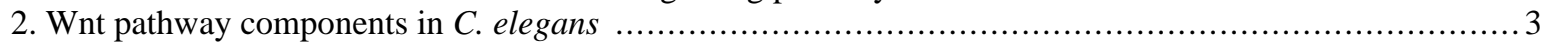

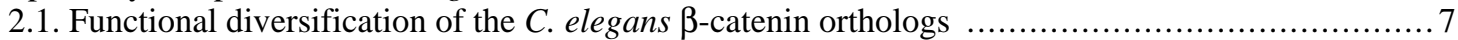

3. Expression of the five Wnt genes during larval development ......................................... 8

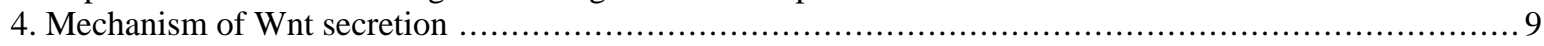

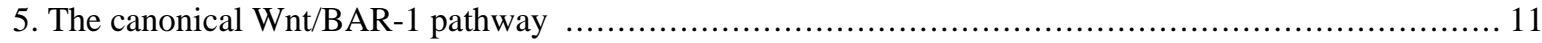

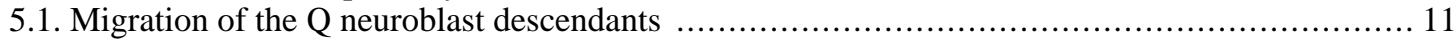

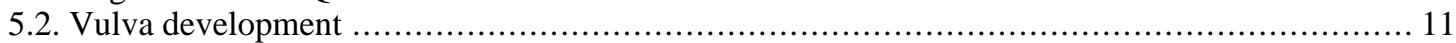

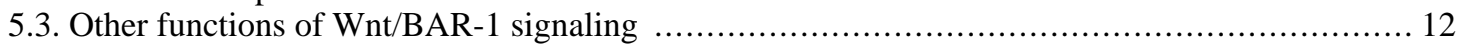

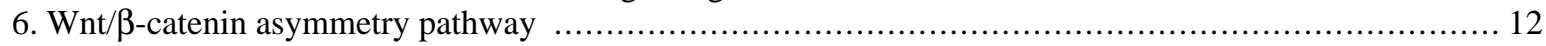

6.1. Asymmetric localization of Wnt signaling components during cell division ........................ 12

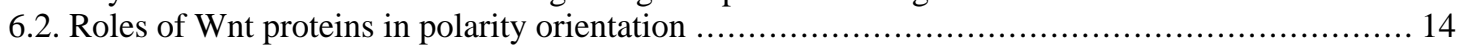

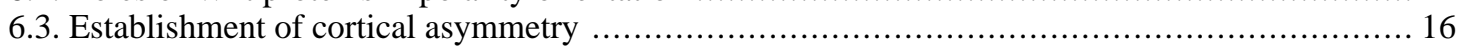

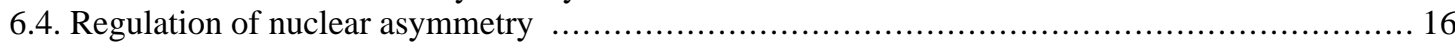

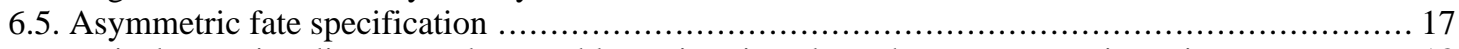

7. Non-canonical Wnt signaling controls neuroblast migration along the anteroposterior axis ................. 18

7.1. HSN migration: function of EGL-20 as a repulsive guidance cue ................................ 18

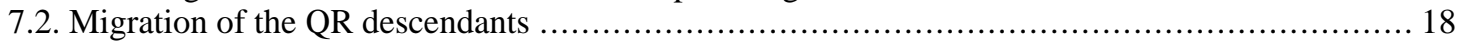

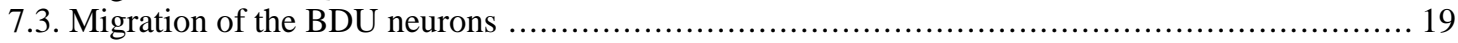

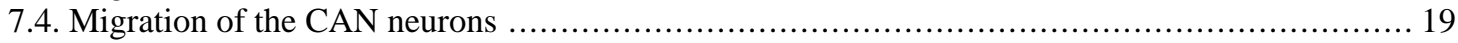

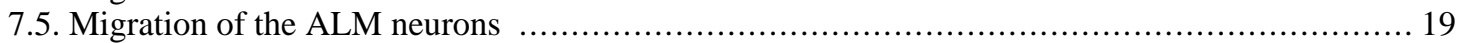

8. Various effects of Wnt signaling on the development and function of the nervous system ................. 19

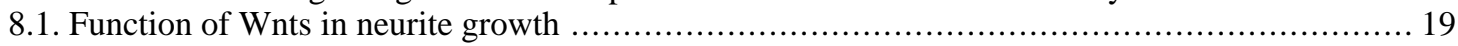

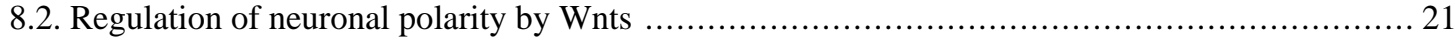

\footnotetext{
*Edited by Iva Greenwald Last revised March 13, 2013, Published December 9, 2013. This chapter should be cited as: Sawa H., Korswagen H. C. Wnt signaling in C. elegans (December 9, 2013), WormBook, ed. The C. elegans Research Community, WormBook, doi/10.1895/wormbook.1.7.2, http://www.wormbook.org.

Copyright: () 2013 Hitoshi Sawa and Hendrik C. Korswagen. This is an open-access article distributed under the terms of the Creative Commons Attribution License, which permits unrestricted use, distribution, and reproduction in any medium, provided the original author and source are credited.

${ }^{\S}$ To whom correspondence should be addressed. E-mail: hisawa@nig.ac.jp or r.korswagen@ hubrecht.eu
} 
8.3. Wnts inhibit neurite elimination

8.4. Wnts regulate synaptic positions

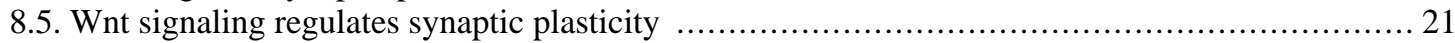

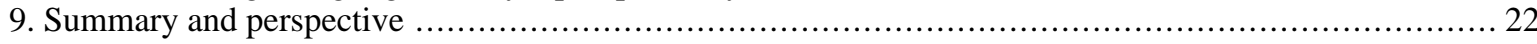

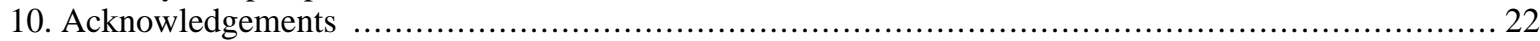

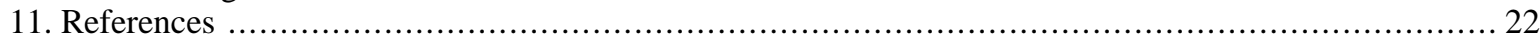

\begin{abstract}
Wnt proteins are secreted lipid-modified glycoproteins that control many aspects of development in organisms ranging from sponges to vertebrates. Wnt proteins are also important regulators of C. elegans development, with functions in processes as diverse as cell fate specification, asymmetric cell division, cell migration and synapse formation. In this review, we will give an overview of what we currently know about the signaling mechanisms that mediate these different functions of Wnt.
\end{abstract}

\title{
1. Introduction
}

During the development of complex multicellular organisms, series of cell fate decisions and morphogenetic movements generate the different tissues and organs of the embryo. A central player in the regulation of these developmental processes is the evolutionarily conserved family of Wnt proteins (Cadigan and Nusse, 1997; Clevers and Nusse, 2012). Wnt proteins are secreted, lipid-modified glycoproteins that can function as short range signaling molecules, but also as morphogens that form concentration gradients to provide positional information to cells in developing tissues (Zecca et al., 1996). Wnt proteins trigger a wide variety of responses, ranging from cell fate specification through the activation of specific target genes to the control of cell polarity and migration through pathways that directly modulate the cytoskeleton (Angers and Moon, 2009). Once development is complete, Wnt signaling is required for stem cell maintenance and tissue regeneration in vertebrates and deregulation of Wnt signaling, such as through mutation of the negative regulator Apc, is frequently associated with cancer (Clevers and Nusse, 2012).

\subsection{Canonical and non-canonical Wnt signaling pathways}

Studies in Drosophila and vertebrates have shown that Wnt proteins can activate several distinct signaling mechanisms. The pathway that has been studied in most detail is the so-called canonical Wnt pathway, which controls the expression of specific target genes through the effector protein $\beta$-catenin (Angers and Moon, 2009; Clevers and Nusse, 2012) (Figure 1). In the absence of Wnt signaling, $\beta$-catenin is targeted for degradation by a destruction complex that consists of the scaffold protein Axin, the tumor suppressor gene product APC, and the kinases CK1 and GSK3 $\beta$. Phosphorylation of $\beta$-catenin on a conserved sequence within the N-terminus (referred to as a phosphodegron sequence) induces $\beta$ Trcp-dependent ubiquitylation and proteasomal degradation. Binding of Wnt to the receptors Frizzled and LRP6 leads to inhibition of $\beta$-catenin degradation through a mechanism that involves the cytoplasmic protein Dishevelled and recruitment of Axin to LRP6 at the plasma membrane. Next, the stabilized $\beta$-catenin translocates to the nucleus, where it interacts with members of the TCF/Lef1 family of HMG-box containing transcription factors to co-activate target gene transcription. 


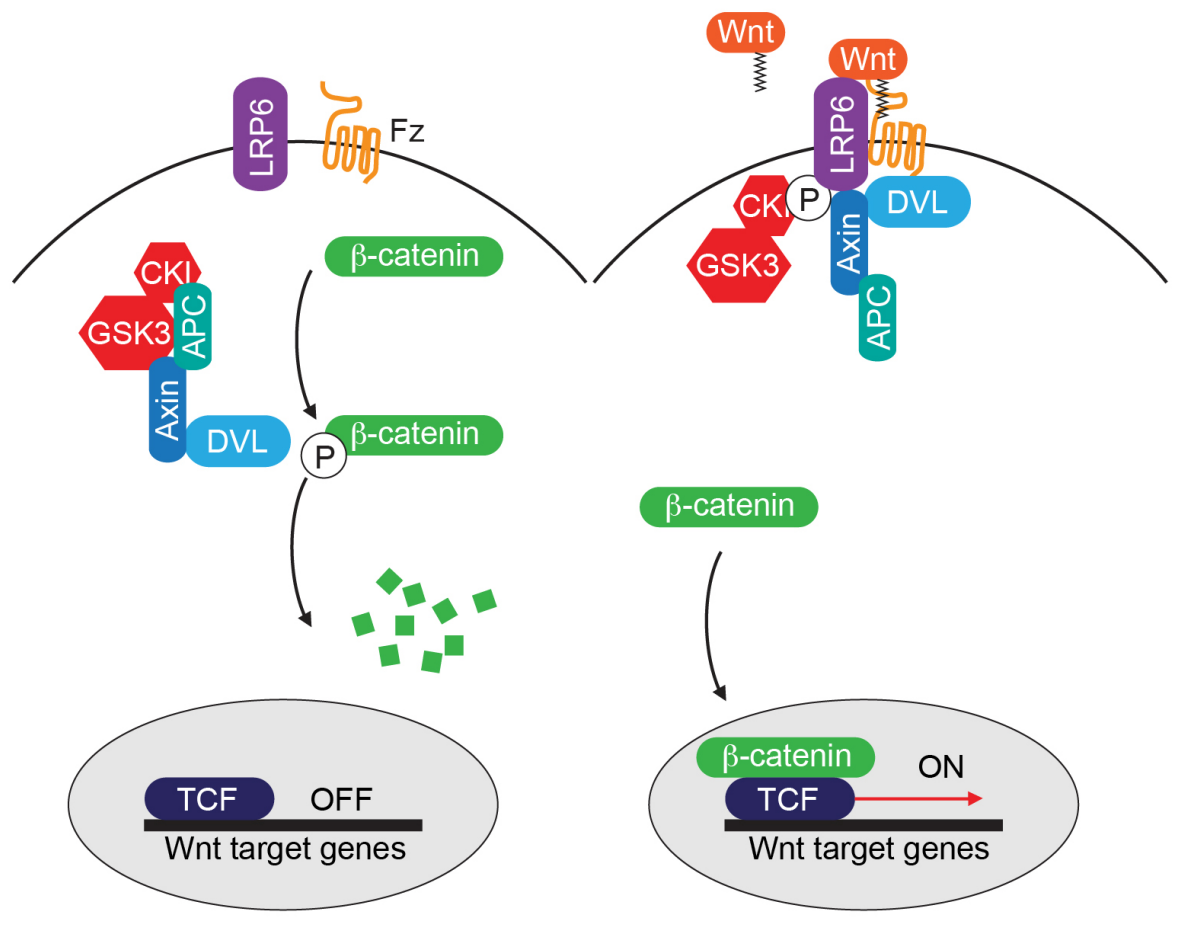

Figure 1. The canonical Wnt/ $\beta$-catenin pathway. Binding of Wnt to the receptors Frizzled (Fz) and LRP6 leads to inhibition of $\beta$-catenin degradation. $\beta$-catenin in turn interacts with members of the TCF/Lef- 1 family of transcription factors to co-activate target gene transcription.

Other Wnt signaling pathways include, among others, the planar cell polarity (PCP) pathway and the Ror and Ryk dependent pathways (Angers and Moon, 2009; Green et al., 2008; Lawrence et al., 2007). A common denominator among these different pathways, which are collectively referred to as non-canonical Wnt pathways, is that they act independently of $\beta$-catenin.

The PCP pathway controls the polarity of cells in the plane of the epithelial sheet and is required for establishing the orientation of hairs and bristles in Drosophila and for the organization of sensory cells in the vertebrate inner ear (Montcouquiol et al., 2003; Torban et al., 2008; Wu and Mlodzik, 2009). In addition, a PCP related pathway is required for the convergence and extension cell movements that drive gastrulation in zebrafish and Xenopus and for neural tube formation in the mouse (Jessen et al., 2002; Torban et al., 2008). Mechanistically, the PCP pathway involves the asymmetric localization of Frizzled, Dishevelled and the PCP pathway components Prickle and Van Gogh (Vangl) (Lawrence et al., 2007; Wallingford, 2012).

Ror is a transmembrane tyrosine-kinase that contains a cysteine-rich Wnt binding domain that is similar to the extracellular domain of Frizzled (Xu and Nusse, 1998). Binding of Wnt to Ror can trigger a variety of responses, ranging from inhibition of canonical Wnt/ $\beta$-catenin signaling to stimulation of cell motility (Green et al., 2008). Ryk (also known as Derailed in Drosophila) is also a transmembrane tyrosine kinase, but in this case Wnt binding is mediated through a domain that is similar to the Wnt binding region of the secreted Wnt inhibitor WIF (Lu et al., 2004; Yoshikawa et al., 2003). Ryk has been shown to function in axon guidance. In addition, signaling through Ryk may modulate canonical Wnt/ $\beta$-catenin pathway activity.

\section{Wnt pathway components in C. elegans}

An overview of Wnt pathway components in C. elegans is presented in Table 1 . The C. elegans genome contains five Wnt genes and four Frizzled receptors (see Wnt signaling; Korswagen, 2002). With the possible exception of LRP6/Arrow, most components of the canonical Wnt/ $\beta$-catenin pathway are conserved. For non-canonical Wnt signaling, there are clear orthologs of the PCP pathway components Vangl and Prickle (Wu and Herman, 2006) and of the Wnt receptors Ror (Forrester et al., 1999) and Ryk (Inoue et al., 2004). 
Table 1. Wnt pathway components in C. elegans

\begin{tabular}{|c|c|c|c|}
\hline Component & C. elegans ortholog & $\begin{array}{c}\text { Reported roles in Wnt } \\
\text { signaling }\end{array}$ & References \\
\hline \multicolumn{4}{|c|}{ Wnt production and secretion } \\
\hline Porcupine & mom-1 & EMS & $\begin{array}{l}\text { (Rocheleau et al., 1997; } \\
\text { Thorpe et al., 1997) }\end{array}$ \\
\hline Wntless & mig-14 & EMS, Q, VPC, OAC, NSF & $\begin{array}{l}\text { (Banziger et al., 2006; } \\
\text { Eisenmann and Kim, 2000; } \\
\text { Harris et al., 1996; Jensen } \\
\text { et al., 2012; Thorpe et al., } \\
\text { 1997) }\end{array}$ \\
\hline Retromer complex & $\begin{array}{l}\text { vps-26, vps-29, vps-35, } \\
\text { snx-3 }\end{array}$ & Q, HSN, SC, NP & $\begin{array}{l}\text { Coudreuse et al., 2006; } \\
\text { Harterink et al., 2011; } \\
\text { Prasad and Clark, 2006; } \\
\text { Yang et al., 2008) }\end{array}$ \\
\hline \multicolumn{4}{|l|}{ Wnt ligands } \\
\hline \multirow[t]{4}{*}{ Wnt ligands } & mom-2 & EMS, VPC, OAC & $\begin{array}{l}\text { (Bischoff and Schnabel, } \\
\text { 2006; Green et al., 2008; } \\
\text { Inoue et al., 2004; Park and } \\
\text { Priess, 2003; Rocheleau et } \\
\text { al., 1997; Thorpe et al., } \\
\text { 1997) }\end{array}$ \\
\hline & $\operatorname{lin}-44$ & $\begin{array}{l}\text { T, P12, VPC, SC, NP, NSF, } \\
\text { OAC }\end{array}$ & $\begin{array}{l}\text { (Green et al., 2008; Herman } \\
\text { and Horvitz, 1994; Herman } \\
\text { et al., 1995; Hilliard and } \\
\text { Bargmann, 2006; Inoue et } \\
\text { al., 2004; Jiang and } \\
\text { Sternberg, 1998; } \\
\text { Kirszenblat et al., 2011; } \\
\text { Klassen and Shen, 2007; } \\
\text { Maro et al., 2009; Prasad } \\
\text { and Clark, 2006; } \\
\text { Yamamoto et al., 2011) }\end{array}$ \\
\hline & egl-20 & $\begin{array}{l}\text { Q, SC, HSN, VPC, NP, } \\
\text { NSF }\end{array}$ & $\begin{array}{l}\text { (Green et al., 2008; Harris } \\
\text { et al., 1996; Hilliard and } \\
\text { Bargmann, 2006; Hunter et } \\
\text { al., 1999; Inoue et al., 2004; } \\
\text { Klassen and Shen, 2007; } \\
\text { Maloof et al., 1999; Pan et } \\
\text { al., 2006; Prasad and Clark, } \\
\text { 2006; Yamamoto et al., } \\
\text { 2011) }\end{array}$ \\
\hline & cwn-1 & Q, HSN, NP, SC, NSF & $\begin{array}{l}\text { (Hayashi et al., 2009; } \\
\text { Hilliard and Bargmann, } \\
\text { 2006; Pan et al., 2006; } \\
\text { Prasad and Clark, 2006; } \\
\text { Yamamoto et al., 2011; } \\
\text { Zinovyeva and Forrester, } \\
\text { 2005; Zinovyeva et al., } \\
\text { 2008) }\end{array}$ \\
\hline
\end{tabular}




\begin{tabular}{|c|c|c|c|}
\hline Component & C. elegans ortholog & $\begin{array}{c}\text { Reported roles in Wnt } \\
\text { signaling }\end{array}$ & References \\
\hline & cwn-2 & $\mathrm{Q}, \mathrm{CAN}, \mathrm{NP}, \mathrm{SC}, \mathrm{NSF}$ & $\begin{array}{l}\text { (Hayashi et al., 2009; } \\
\text { Jensen et al., 2012; } \\
\text { Kennerdell et al., 2009; } \\
\text { Prasad and Clark, 2006; } \\
\text { Song et al., 2010; } \\
\text { Yamamoto et al., 2011; } \\
\text { Zinovyeva and Forrester, } \\
\text { 2005; Zinovyeva et al., } \\
\text { 2008) }\end{array}$ \\
\hline \multicolumn{4}{|l|}{ Wnt receptors } \\
\hline \multirow[t]{4}{*}{ Frizzled } & mom-5 & EMS, Q, SC, OAC, NSF & $\begin{array}{l}\text { (Pan et al., 2006; Park and } \\
\text { Priess, 2003; Park et al., } \\
\text { 2004; Rocheleau et al., } \\
\text { 1997; Thorpe et al., 1997; } \\
\text { Yamamoto et al., 2011; } \\
\text { Zinovyeva et al., 2008) }\end{array}$ \\
\hline & $\operatorname{lin}-17$ & $\begin{array}{l}\text { T, Q, SC, P12, Z, NP, NSF, } \\
\text { OAC }\end{array}$ & $\begin{array}{l}\text { (Harris et al., 1996; Hilliard } \\
\text { and Bargmann, 2006; } \\
\text { Jensen et al., 2012; Jiang } \\
\text { and Sternberg, 1998; } \\
\text { Kirszenblat et al., 2011; } \\
\text { Klassen and Shen, 2007; } \\
\text { Prasad and Clark, 2006; } \\
\text { Sawa et al., 1996; Siegfried } \\
\text { and Kimble, 2002; } \\
\text { Sternberg and Horvitz, } \\
\text { 1988; Yamamoto et al., } \\
\text { 2011; Zinovyeva et al., } \\
\text { 2008) }\end{array}$ \\
\hline & mig-1 & Q, HSN, SC, NSF & $\begin{array}{l}\text { (Harris et al., 1996; } \\
\text { Kennerdell et al., 2009; Pan } \\
\text { et al., 2006; Song et al., } \\
\text { 2010) }\end{array}$ \\
\hline & $c f z-2$ & ALM, Q, NSF & $\begin{array}{l}\text { (Song et al., 2010; } \\
\text { Zinovyeva and Forrester, } \\
\text { 2005) }\end{array}$ \\
\hline LRP6/Arrow & $?$ & & \\
\hline Ror & cam-1 & HSN, CAN, NSF, VPC, SC & $\begin{array}{l}\text { (Forrester et al., 1999; } \\
\text { Forrester et al., 2004; Green } \\
\text { et al., 2008; Jensen et al., } \\
\text { 2012; Song et al., 2010; } \\
\text { Kennerdell et al., 2009; } \\
\text { Yamamoto et al., 2011; } \\
\text { Hayashi et al., 2009) }\end{array}$ \\
\hline Ryk/Derailed & $\operatorname{lin}-18$ & VPC, NSF & $\begin{array}{l}(\text { Inoue et al., 2004; Pan et } \\
\text { al., 2006) }\end{array}$ \\
\hline \multicolumn{4}{|c|}{ Secreted Wnt inhibitors } \\
\hline Sfrp & $s f r p-1$ & Q, ALM, CAN & (Harterink et al., 2011) \\
\hline \multicolumn{4}{|c|}{ Wnt/B-catenin pathway components } \\
\hline
\end{tabular}




\begin{tabular}{|c|c|c|c|}
\hline Component & C. elegans ortholog & $\begin{array}{l}\text { Reported roles in Wnt } \\
\text { signaling }\end{array}$ & References \\
\hline CK1 & kin-19 & EMS, SC & $\begin{array}{l}\text { (Banerjee et al., 2010; } \\
\text { Peters et al., 1999) }\end{array}$ \\
\hline \multirow[t]{3}{*}{ Dishevelled } & mig-5 & EMS, Q, Z, OAC & $\begin{array}{l}\text { (Walston et al., 2006; } \\
\text { Walston et al., 2004) }\end{array}$ \\
\hline & $d s h-1$ & EMS, OAC, NSF & $\begin{array}{l}\text { (Jensen et al., 2012; } \\
\text { Klassen and Shen, 2007; } \\
\text { Sanchez-Alvarez et al., } \\
\text { 2011; Song et al., 2010; } \\
\text { Walston et al., 2004) }\end{array}$ \\
\hline & $d s h-2$ & EMS, Z, OAC & $\begin{array}{l}\text { (Hawkins et al., 2005; King } \\
\text { et al., 2009; Phillips et al., } \\
\text { 2007; Walston et al., 2004) }\end{array}$ \\
\hline GSK3 $\beta$ & $g s k-3$ & Q & $\begin{array}{l}\text { (Korswagen et al., 2002; } \\
\text { Rocheleau et al., 1997) }\end{array}$ \\
\hline \multirow[t]{2}{*}{ Axin } & pry-1 & $\mathrm{Q}, \mathrm{SC}, \mathrm{VPC}, \mathrm{P} 12$ & $\begin{array}{l}\text { (Gleason et al., 2002; } \\
\text { Korswagen et al., 2002; } \\
\text { Maloof et al., 1999; } \\
\text { Whangbo et al., 2000) }\end{array}$ \\
\hline & axl-1 & & (Oosterveen et al., 2007) \\
\hline APC & apr-1 & EMS, VPC, T, SC & $\begin{array}{l}\text { (Hoier et al., 2000; } \\
\text { Mizumoto and Sawa, 2007; } \\
\text { Rocheleau et al., 1997) }\end{array}$ \\
\hline$\beta \operatorname{Trcp}$ & $\operatorname{lin}-23$ & NSF & (Dreier et al., 2005) \\
\hline Nlk & lit-1 & EMS, T, Z, SC, OAC & $\begin{array}{l}\text { (Bertrand and Hobert, } \\
\text { 2009; Kaletta et al., 1997; } \\
\text { Meneghini et al., 1999; } \\
\text { Rocheleau et al., 1999; } \\
\text { Siegfried and Kimble, } \\
\text { 2002; Takeshita and Sawa, } \\
\text { 2005) }\end{array}$ \\
\hline Tak1 & mom-4 & EMS, T, SC, OAC & $\begin{array}{l}\text { (Bertrand and Hobert, } \\
\text { 2009; Meneghini et al., } \\
\text { 1999; Shin et al., 1999; } \\
\text { Takeshita and Sawa, 2005) }\end{array}$ \\
\hline Tab1 & tap-1 & EMS & (Meneghini et al., 1999) \\
\hline \multirow[t]{3}{*}{$\beta$-catenin } & bar-1 & $\mathrm{Q}, \mathrm{VPC}, \mathrm{P} 12, \mathrm{NSF}$ & $\begin{array}{l}\text { (Dreier et al., 2005; } \\
\text { Eisenmann et al., 1998; } \\
\text { Korswagen et al., 2000; } \\
\text { Maloof et al., 1999; } \\
\text { Natarajan et al., 2001) }\end{array}$ \\
\hline & sys-1 & EMS, Z, T & $\begin{array}{l}\text { (Kidd et al., 2005; Phillips } \\
\text { et al., 2007; Huang et al., } \\
\text { 2007) }\end{array}$ \\
\hline & wrm-1 & EMS, Z, T, SC, OAC & $\begin{array}{l}\text { (Phillips et al., 2007; } \\
\text { Rocheleau et al., 1997; } \\
\text { Rocheleau et al., 1999; } \\
\text { Takeshita and Sawa, 2005; } \\
\text { Bertrand and Hobert, 2009; } \\
\text { Gleason and Eisenmann, } \\
\text { 2010; King et al., 2009) }\end{array}$ \\
\hline
\end{tabular}




\begin{tabular}{|c|c|c|c|}
\hline Component & C. elegans ortholog & $\begin{array}{c}\text { Reported roles in Wnt } \\
\text { signaling }\end{array}$ & References \\
\hline & $h m p-2$ & EMS, Adherens junctions & $\begin{array}{l}\text { (Costa et al., 1998; } \\
\text { Korswagen et al., 2000; } \\
\text { Natarajan et al., 2001; } \\
\text { Putzke and Rothman, 2010; } \\
\text { Sumiyoshi et al., 2011) }\end{array}$ \\
\hline Tcf & pop-1 & $\begin{array}{l}\text { EMS, Q, SC, VPC, T, Z, } \\
\text { OAC }\end{array}$ & $\begin{array}{l}\text { (Bertrand and Hobert, } \\
\text { 2009; Gleason and } \\
\text { Eisenmann, 2010; Herman, } \\
\text { 2001; Korswagen et al., } \\
\text { 2000; Lin et al., 1998; Lin } \\
\text { et al., 1995; Rocheleau et } \\
\text { al., 1997; Siegfried and } \\
\text { Kimble, 2002; Thorpe et } \\
\text { al., 1997) }\end{array}$ \\
\hline Groucho & unc-37 & EMS & (Calvo et al., 2001) \\
\hline \multicolumn{4}{|c|}{ PCP pathway components } \\
\hline Vangl & vang-1 & B, VPC, NSF & $\begin{array}{l}\text { (Green et al., 2008; Hayashi } \\
\text { et al., 2009; } \\
\text { Sanchez-Alvarez et al., } \\
\text { 2011; Wu and Herman, } \\
\text { 2006) }\end{array}$ \\
\hline Prkl & prkl-1 & NSF & $\begin{array}{l}\text { (Sanchez-Alvarez et al., } \\
\text { 2011; Wu and Herman, } \\
\text { 2006) }\end{array}$ \\
\hline Flamingo & fmi-1 & NSF & $\begin{array}{l}\text { (Najarro et al., 2012; } \\
\text { Steimel et al., 2010) }\end{array}$ \\
\hline \multicolumn{4}{|c|}{$\begin{array}{l}\text { Wnt phenotypes are indicated as EMS polarity (EMS), seam cell polarity (SC), T cell polarity (T), other } \\
\text { asymmetric cell divisions (OAC), Q, HSN, CAN or ALM cell migration (Q, HSN, CAN, ALM), vulva induction } \\
\text { and P7.p polarity (VPC), P12 fate specification (P12), Z1/4 polarity (Z), nervous system function and development } \\
\text { (NSF) and neuronal polarity (NP). }\end{array}$} \\
\hline
\end{tabular}

\subsection{Functional diversification of the $C$. elegans $\beta$-catenin orthologs}

In Drosophila and vertebrates, $\beta$-catenin has a dual function in cell adhesion and Wnt signaling. It binds to the cytoplasmic tail of classical cadherins and $\alpha$-catenin to anchor the actin cytoskeleton to adherens junctions and interacts with TCF/Lef-1 transcription factors to activate Wnt target gene expression (Cadigan and Nusse, 1997; Clevers and Nusse, 2012). Interestingly, it was found that these different functions are mediated by four separate $\beta$-catenins in C. elegans: BAR-1, WRM-1, SYS-1 and HMP-2 (Robertson and Lin, 2012).

The $\beta$-catenin that mediates canonical Wnt signaling is BAR-1. It contains a conserved phosphodegron sequence (Korswagen et al., 2000) and binds to the Axin orthologs PRY-1 (Korswagen et al., 2002) and AXL-1 (Oosterveen et al., 2007), the APC ortholog APR-1 and GSK-3/GSK3 $\beta$ (Korswagen et al., 2002), indicating that BAR-1 stability is regulated by a conserved destruction complex. BAR-1 also binds to the TCF transcription factor POP-1 and co-activates transcription in reporter gene assays (Korswagen et al., 2000; Natarajan et al., 2001).

The $\beta$-catenins SYS-1 and WRM-1 are part of a divergent canonical Wnt/ $\beta$-catenin pathway (the $\mathrm{Wnt} / \beta$-catenin asymmetry pathway) that controls asymmetric cell divisions along the anteroposterior axis (Kidd et al., 2005; Rocheleau et al., 1997). As discussed in Section 6, this pathway restricts Wnt target gene expression to posterior daughter cells by downregulating nuclear POP-1 and simultaneously upregulating SYS-1 levels. Like $\beta$-catenins in Drosophila and vertebrates, SYS-1 binds to POP-1 and co-activates target gene expression (Kidd et al., 2005). However, the regulation of SYS-1 stability appears to be different from that of BAR-1. Thus, although the asymmetry in SYS-1 levels is dependent on apr-1/APC in the early embryo (Huang et al., 2007), no role for destruction complex components was found in specifying SYS-1 asymmetry in somatic gonad development 
Phillips et al., 2007). Downregulation of nuclear POP-1 is mediated by WRM-1, which binds to and activates the kinase LIT-1/Nlk to induce nuclear export of POP-1 (Lo et al., 2004; Meneghini et al., 1999; Rocheleau et al., 1999; Shin et al., 1999; Yang et al., 2011).

The $\beta$-catenin HMP-2 interacts with the classical cadherin HMR-1 and with the $\alpha$-catenin HMP-1 (Korswagen et al., 2000; Natarajan et al., 2001) and co-localizes with these proteins in adherens junctions (Costa et al., 1998). Interestingly, BAR-1 and WRM-1 do not interact with HMR-1, while HMP-2 does not bind to POP-1 and PRY-1 (Korswagen et al., 2002; Korswagen et al., 2000; Natarajan et al., 2001), indicating that the function of $\beta$-catenin in Wnt signaling and cell adhesion has been divided over separate $\beta$-catenins in $C$. elegans. It should be noted, however, that recent studies suggest that hmp-2 may have an additional function as part of a Fer and Src kinase-dependent pathway that acts in parallel to the Wnt/ $\beta$-catenin asymmetry pathway in endoderm induction in the early embryo (Putzke and Rothman, 2010; Sumiyoshi et al., 2011).

\section{Expression of the five Wnt genes during larval development}

The expression patterns of the five Wnt genes of $C$. elegans have been extensively studied using traditional transgenic reporter gene based assays (Gleason et al., 2006; Herman et al., 1995; Kennerdell et al., 2009; Pan et al., 2006; Song et al., 2010; Whangbo and Kenyon, 1999) and a novel single molecule mRNA fluorescent in situ hybridization (smFISH) approach (Harterink et al., 2011; Raj et al., 2008). The advantage of smFISH is that it measures endogenous gene expression with single mRNA resolution in vivo, providing both spatial and quantitative information on gene expression (see Single molecule fluorescent in situ hybridization (smFISH) of C. elegans worms and embryos; Raj et al., 2008). The general picture that emerges from these studies is that during early larval development the five Wnt genes are predominantly expressed in the posterior body region in a series of partially overlapping expression domains (Figure 2).

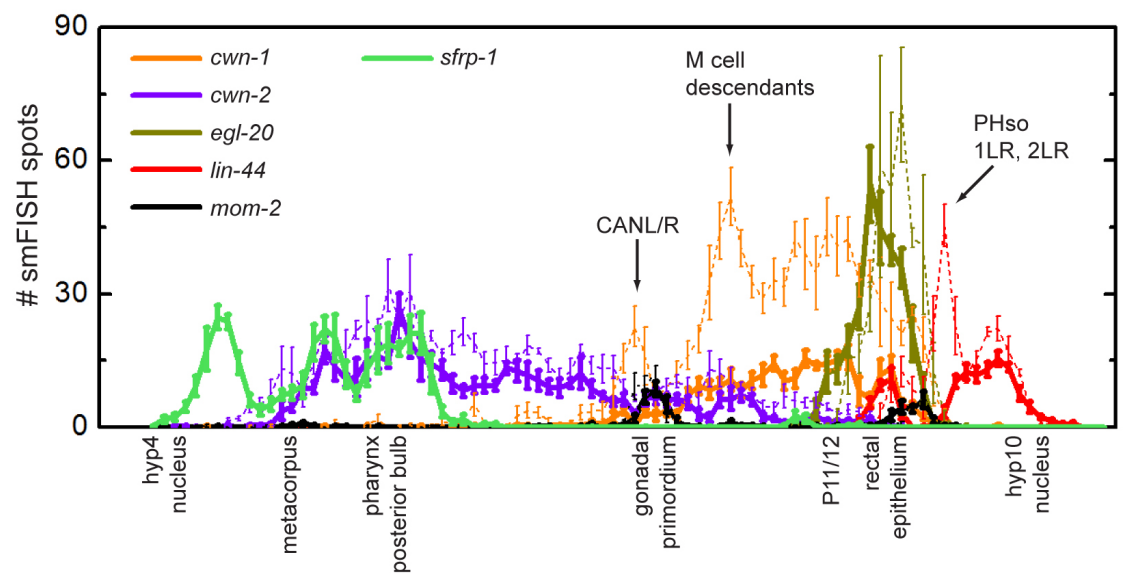

Figure 2. Single molecule mRNA FISH (smFISH) analysis of the five $\boldsymbol{C}$. elegans Wnt genes and $\boldsymbol{s f r p}$ - 1 . Expression was quantified as smFISH spots per unit distance along the anteroposterior axis of early (closed lines) and late (dotted lines) L1 larvae. Note the mostly posterior expression of the Wnt genes in partially overlapping domains and the anterior expression of sfrp-1. Figure adapted from (Harterink et al., 2011).

Going from posterior to anterior at the L1 larval stage, the Wnt gene expressed in the most posterior domain is lin-44, with prominent expression in the tail hypodermal cells hyp8, hyp9, hyp10 and hyp11 (Harterink et al., 2011; Herman et al., 1995). In addition, lin-44 mRNA is present in the rectal epithelial cells B and Y, showing that lin-44 has a more anterior expression domain than has been observed with reporter transgenes. At later larval stages, lin-44 is also expressed in the phasmid socket cells PHso1 and PHso2 and in the anchor cell (Herman et al., 1995; Inoue et al., 2004).

Moving anteriorly, the next posterior Wnt gene is egl-20, with expression in the rectal epithelial cells K, F, U and B, the anal depressor muscle, and P11/12 (Pan et al., 2006; Whangbo and Kenyon, 1999). In addition, egl-20 mRNA is detected in the posterior ventral body wall muscle quadrants VL23 and VR24, and the rectal epithelial cell Y (Harterink et al., 2011).

The third Wnt expression domain is occupied by $c w n-1$, with expression in posterior body wall muscle cells as well as the $\mathrm{M}$ cell descendants that give rise to body wall muscle cells and the vulva and uterine muscle cells (Gleason et al., 2006; Harterink et al., 2011; Pan et al., 2006). In addition, several cells co-express cwn-1 and egl-20, including the anal depressor muscle, the body wall muscle quadrants VL23 and VR24, and P11/12. Interestingly, the 
two lateral canal associated neurons (CANs) simultaneously activate $c w n-1$ expression during late $\mathrm{L} 1$, an expression that persists throughout larval development.

At the anterior end of the spectrum is the expression domain of $c w n-2$. Although an initial study using reporter fusions suggested that $c w n-2$ is expressed along the entire length of the animal in body wall muscle cells and ventral nerve cord neurons (Gleason et al., 2006), later studies suggested a more restricted expression in the pharynx, anterior muscle cells, and the intestine (Kennerdell et al., 2009; Song et al., 2010). This result was confirmed by smFISH analysis, showing $c w n-2$ transcripts mainly in head neurons, anterior body wall muscle cells, anterior P.n cells and the intestine. The highest $c w n-2$ transcript count was observed around the terminal bulb of the pharynx, with a gradual decline in expression levels in more posterior cells. The mostly anterior expression of $c w n-2$ and posterior expression of $c w n-l$ was already observed at the 100 cell stage of embryonic development (Harterink et al., 2011).

The fifth Wnt gene, mom-2, was previously reported to be widely expressed along the anteroposterior axis, with expression in body wall muscle cells, ventral cord neurons, intestinal cells, and seam cells (Gleason et al., 2006). Analysis of mom-2 mRNA localization revealed that mom-2 shows a more restricted expression pattern, with mom-2 transcripts localizing to the germ cell precursors Z2 and Z3 and their descendants, and a few unidentified cells in the tail. The expression of mom-2 in the germ cells continues throughout larval development, while the tail expression reaches a maximum at the mid L1 stage and disappears before the L1 to L2 molt (Harterink et al., 2011). At the L3 stage, mom-2 is also expressed in the anchor cell (Inoue et al., 2004). Consistent with the early embryonic function of mom-2 (Rocheleau et al., 1997; Thorpe et al., 1997), mom-2 transcripts are already present in the zygote. At the 4-cell stage, mom-2 transcripts are enriched in the P2 blastomere. During later stages of embryonic development, mom-2 transcripts are restricted to the posterior, with expression remaining in the tail and the $\mathrm{Z} 2$ and Z3 germ line precursors in comma stage embryos.

It has been well established in Drosophila and vertebrates that Wnts can act as morphogens, forming long-range concentration gradients that provide positional information to cells in developing tissues (Cadigan and Nusse, 1997). By expressing a tagged version of EGL-20, it has been shown that EGL-20 forms a concentration gradient in L1 larvae that ranges from the expressing cells in the tail to the mid-body region (Coudreuse et al., 2006). This is in agreement with the different functions of EGL-20 in the posterior body region, including its role as a repulsive guidance cue in HSN migration (Pan et al., 2006). Whether the other Wnts also form long-range concentration gradients remains to be established.

The activity of Wnt proteins is modulated by secreted Wnt inhibitory proteins such as Dickkopf (Dkk) (Glinka et al., 1998), Wnt inhibitory factor (WIF) (Hsieh et al., 1999), and members of the secreted Frizzled related proteins (SFRPs), an ancient family of Wnt regulators that are present in organism ranging from sponges to vertebrates (Bovolenta et al., 2008). Although orthologs of Dkk and WIF appear to be absent, the $C$. elegans genome does contain a single SFRP ortholog encoded by the gene sfrp-l (Harterink et al., 2011) (Table 1). sfrp-1 is expressed in the four head muscle quadrants (Figure 2), an anterior specific expression that is already present at the 100- cell stage of embryonic development. The anterior expression of sfrp-1 indicates that SFRP-1 counteracts the more posteriorly expressed Wnts. Indeed, it was shown that SFRP-1 functions as a general inhibitor of Wnt signaling that represses the activity of $\mathrm{CWN}-2$ and $\mathrm{CWN}-1$ in the anterior body region to control the migration of the $\mathrm{QR}$ descendants and the CAN and ALM neurons (Harterink et al., 2011).

The expression of the different Wnt genes in a series of partially overlapping domains along the anteroposterior body axis is remarkably similar to the staggered expression of Wnt genes in cnidarians and planarians (Kusserow et al., 2005; Petersen and Reddien, 2008). It has been proposed that this staggered expression provides an ancestral mechanism for providing positional identity along the primary body axis (Guder et al., 2006; Martin and Kimelman, 2009) and an interesting possibility is that such a Wnt code is also important in providing positional information during $C$. elegans development. In addition, the anterior expression of the Wnt inhibitor SFRP-1 and the mostly posterior expression of the different Wnt genes is similar to the expression of Wnts and Wnt inhibitors in cnidarians, planarians and vertebrates (Petersen and Reddien, 2009), consistent with the notion that opposing expression of Wnts and Wnt inhibitors is an important evolutionarily conserved mechanism in primary body axis specification.

\section{Mechanism of Wnt secretion}

Wnts are lipid modified glycoproteins that require a specialized secretory pathway to be released from producing cells (Figure 3). Wnt proteins are acylated at a serine residue (S209 in mouse Wnt3a) that is conserved in 
most Wnt proteins (Takada et al., 2006; Willert et al., 2003), including the five C. elegans Wnts. The lipid modification is mediated by the ER-localized acyl-transferase Porcupine (Takada et al., 2006). In C. elegans, mutation of the Porcupine ortholog mom- 1 induces a defect in the MOM-2/Wnt dependent induction of endoderm fate (Rocheleau et al., 1997; Thorpe et al., 1997), indicating that mom-1 is also essential for Wnt signaling in $C$. elegans. A function of MOM-1 in lipid modification of Wnt has however not been demonstrated biochemically.

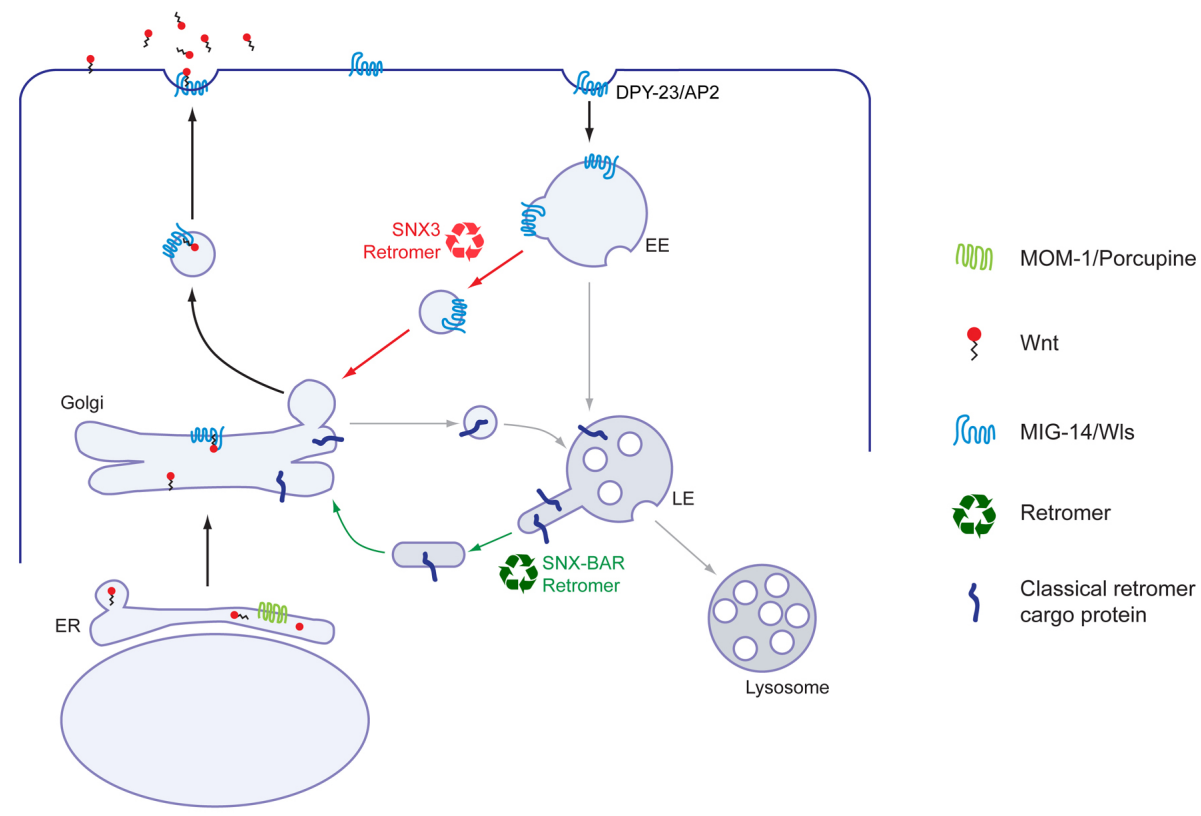

Figure 3. The Wnt secretion pathway. Wnt is lipid modified in the ER (most likely by MOM-1/Porcupine) and is transported from the Golgi to the cell surface by the Wnt sorting receptor MIG-14/Wls. Next, MIG-14 is recycled back to the Golgi through DPY-23/AP2 mediated endocytosis and a retromer dependent endosome-to-Golgi retrieval pathway. Retrieval of MIG-14/Wls is mediated by a specialized retromer pathway that depends on the sorting nexin SNX-3 instead of the classical SNX-BAR sorting nexins $\operatorname{sn} x-1$ and $\operatorname{sn} x-6$. See text for references.

Once Wnt is lipid-modified and glycosylated, it is transported from the ER to the Golgi network through a p24-dependent trafficking mechanism (Buechling et al., 2011; Port et al., 2011). Here, it meets the Wnt binding protein Wntless (Wls), which transports Wnt from the Golgi to the cell surface for release (Lorenowicz and Korswagen, 2009; Port and Basler, 2010). Null mutants of the C. elegans Wls ortholog MIG-14 (also known as MOM-3) show a similar phenotype as mom-2/Wnt mutants: a defect in endoderm induction and in the orientation of the mitotic spindle of the ABar blastomere (Banziger et al., 2006; Thorpe et al., 1997). In addition, weaker alleles and maternally rescued mig-14 null mutants show a wide range of other Wnt related phenotypes-including defects in asymmetric cell divisions, vulva induction, and neuroblast migration (Eisenmann and Kim, 2000; Harris et al., 1996; Whangbo et al., 2000)—indicating that MIG-14 is essential for Wnt secretion in C. elegans as well.

Current models suggest that once the Wnt protein is released, MIG-14/Wls is recycled back to the Golgi to take part in new rounds of Wnt secretion (Lorenowicz and Korswagen, 2009; Port and Basler, 2010). The first step in this retrieval pathway is endocytosis from the plasma membrane through AP2 adaptor complex-dependent endocytosis (Pan et al., 2008; Yang et al., 2008). Next, MIG-14 is retrieved from the endolysosomal system and transported to the trans-Golgi network (TGN) by a retromer-dependent trafficking pathway. The retromer binds Wls through a cargo-selective subcomplex that consists of the subunits VPS-26, VPS-29 and VPS-35 (Belenkaya et al., 2008; Port et al., 2008). In null mutants of the cargo-selective subunits, internalized MIG-14 is degraded in the lysosomal system (Pan et al., 2008; Yang et al., 2008). As a result, less MIG-14 is available in the Golgi to mediate Wnt secretion, leading to a range of Wnt-related phenotypes (Coudreuse et al., 2006; Prasad and Clark, 2006).

The retromer has an evolutionarily conserved function in endosome to TGN transport of lysosomal sorting receptors such as Vps10p in yeast and the cation-independent mannose 6-phosphate receptor in mammalian cells (Cullen and Korswagen, 2012). The cargo-selective subcomplex of the retromer associates with heterodimers of the sorting nexins SNX1/2 and SNX5/6 to mediate the membrane remodeling that is necessary to sort these cargo proteins into specific tubular transport carriers (Cullen and Korswagen, 2012). Interestingly, the endosome to TGN transport of MIG-14 is independent of the C. elegans SNX1/2 and SNX5/6 orthologs snx-1 and snx-6 (Harterink et al., 2011). Instead, MIG-14 retrieval is dependent on the unrelated sorting nexin SNX-3, which sorts MIG-14/Wls 
into vesicular transport carriers that are morphologically distinct from the tubular carriers that are formed by the classical retromer complex. SNX-3 is recruited to endosomal membranes through a phosphatidylinositol 3-monophosphate (PI3P)-binding PX domain. This endosomal association is regulated by the myotubularin lipid phosphatases MTM-6 and MTM-9, and MIG-14 retrieval is strongly disrupted in their absence (Silhankova et al., 2010). Why MIG-14/Wls retrieval is mediated through a specialized retromer pathway remains to be established.

\section{The canonical Wnt/BAR-1 pathway}

The Wnt/BAR-1 pathway is primarily required during larval development, with functions in Q neuroblast migration, vulva development, P12 fate specification, and the generation of seam cell-derived structures such as the postdeirid and male rays (see the WormBook chapter Wnt signaling; Korswagen, 2002). The main targets of the Wnt/BAR-1 pathway appear to be the Hox genes lin-39, mab-5, and egl-5.

\subsection{Migration of the $Q$ neuroblast descendants}

At the end of embryogenesis, two Q neuroblasts are generated at equivalent positions on the left and right lateral sides of the animal (Figure 4). Both Q cells produce an identical set of descendants, but the migration of these descendants is in opposite directions: on the left side the QL descendants (QL.d) migrate towards the posterior, while on the right side the QR.d migrate towards the anterior (Sulston and Horvitz, 1977). The difference in migration direction is specified by EGL-20/Wnt signaling (Harris et al., 1996; Korswagen et al., 2002; Korswagen et al., 2000; Maloof et al., 1999). Through a mechanism that appears to involve a difference in response threshold to EGL-20 (Whangbo and Kenyon, 1999), canonical Wnt/BAR-1 signaling and expression of the target gene mab-5/Hox is only activated in QL. As a consequence, the QL.d migrate towards the posterior, while the QR.d migrate in the default anterior direction. Mutations that disrupt Wnt/BAR-1 signaling, such as mutations in mig-14/Wls (Harris et al., 1996), vps-35/retromer (Coudreuse et al., 2006), snx-3/sorting nexin (Harterink et al., 2011), egl-20/Wnt (Maloof et al., 1999), lin-17/Fz, mig-1/Fz (Harris et al., 1996), mig-5/Dsh (Walston et al., 2006), bar-1/ $\beta$-catenin (Eisenmann et al., 1998; Korswagen et al., 2000), and pop-1/Tcf (Herman, 2001; Korswagen et al., 2000), disrupt mab-5 expression in QL, resulting in anterior migration of the QL.d. Conversely, constitutive activation of the pathway through mutation of pry-1/Axin, overexpression of egl-20/Wnt, or a constitutively active $\mathrm{N}$-terminally truncated bar- $1 / \beta$-catenin, induces ectopic expression of $m a b-5$ in $\mathrm{QR}$ and posterior migration of the QR.d (Korswagen et al., 2002; Maloof et al., 1999; Whangbo and Kenyon, 1999).
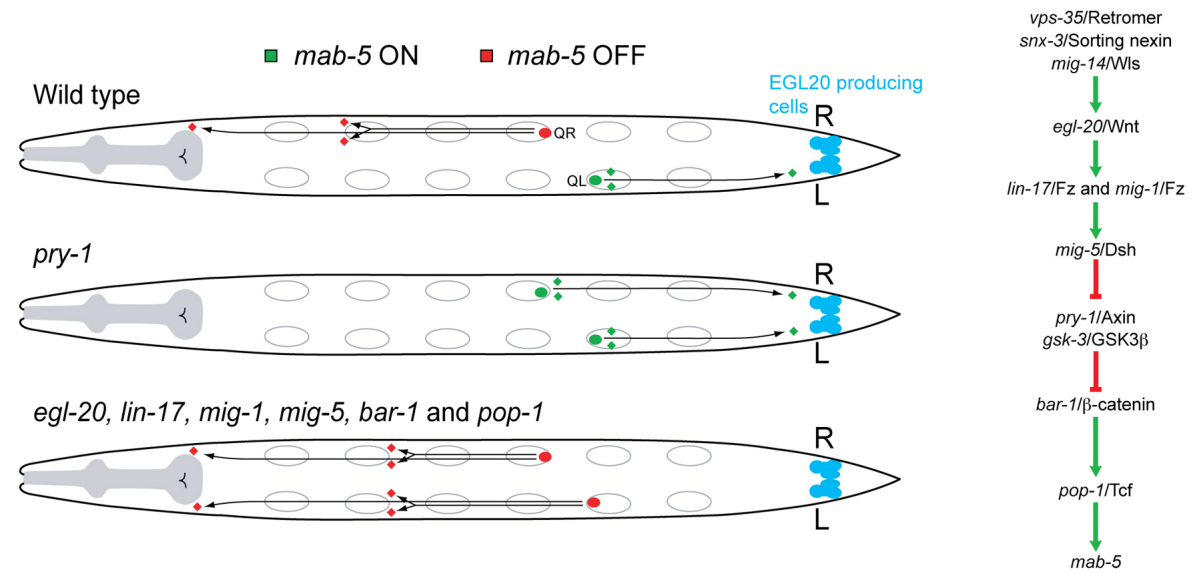

Figure 4. The Wnt dependent migration of the $\mathbf{Q}$ neuroblast descendants. EGL-20/Wnt signaling activates the Hox gene mab-5 in QL to induce posterior migration of the QL descendants (QL.d). mab-5 is not activated in QR and as a consequence, the QR.d migrate in the default anterior direction. In mutants that disrupt EGL-20 signaling, mab-5 fails to be expressed in QL and the QL.d migrate towards the anterior. In pry-1/Axin mutants, mab-5 is ectopically expressed in QR and the QR.d migrate towards posterior positions.

\subsection{Vulva development}

The vulva develops from six vulva precursor (VPCs) cells that are located at the ventral midline (see Vulval development). The VPCs respond to an inductive LIN-3/EGF signal from the somatic gonad to generate the cells that form the vulva opening. Wnt signaling has a permissive role in maintaining VPC competence and preventing fusion of the VPCs with the surrounding hypodermal syncytium (Eisenmann et al., 1998; Gleason et al., 2002; Gleason et al., 2006; Myers and Greenwald, 2007). The main Wnt ligands involved are CWN-1 and EGL-20, which 
signal through a canonical Wnt/BAR-1 pathway to induce expression of the Hox gene lin-39 (Gleason et al., 2002; Gleason et al., 2006; Myers and Greenwald, 2007). Overactivation of the pathway through mutation of pry-1/Axin or overexpression of constitutively active $\mathrm{N}$-terminally truncated $b a r-1 / \beta$-catenin leads to an overinduced phenotype in which multiple VPCs adopt a vulval fate (Gleason et al., 2002). At a later stage in vulva morphogenesis, BAR-1 signaling in the P7.p descendants is modulated by the Ryk ortholog LIN-18 (Inoue et al., 2004).

\subsection{Other functions of Wnt/BAR-1 signaling}

The Wnt/BAR-1 pathway also controls specification of the posterior hypodermal cell P12 (Jiang and Sternberg, 1998) and the formation of rays from seam cells in the male tail (Zhang and Emmons, 2000). Furthermore, BAR-1 dependent Wnt signaling is repressed in the V5 seam cell lineage to allow postdeirid formation (Hunter et al., 1999). In each of these cases, Wnt/BAR-1 signaling controls the expression Hox genes.

\section{Wnt/B-catenin asymmetry pathway}

\subsection{Asymmetric localization of Wnt signaling components during cell division}

A divergent canonical Wnt signaling pathway called the Wnt/3-catenin asymmetry pathway controls a number of asymmetric cell divisions of somatic cells that occur along the anterior-posterior axis (Mizumoto and Sawa, 2007). For example, the EMS blastomere in the embryo and $\mathrm{T}$ cell in the larva receive Wnt signals from their posterior neighbors: the EMS blastomere receives MOM-2 from the P2 blastomere (Rocheleau et al., 1997; Thorpe et al., 1997), and the T cell receives LIN-44 from the hyp10/11 cells (Herman et al., 1995) (Figure 5). Each of these signals causes polarization of the cells and asymmetry in the fates of their daughters. In the EMS division, the MS daughters have a mesodermal fate, and the $\mathrm{E}$ daughters have an endodermal fate; in the $\mathrm{T}$ cell division, the T.a daughters have a hypodermal fate, and the T.p daughters a neural fate. Abnormalities in this pathway cause the loss of asymmetry or the reversal of the daughters' cell fates. 
(A) anterior

(a)

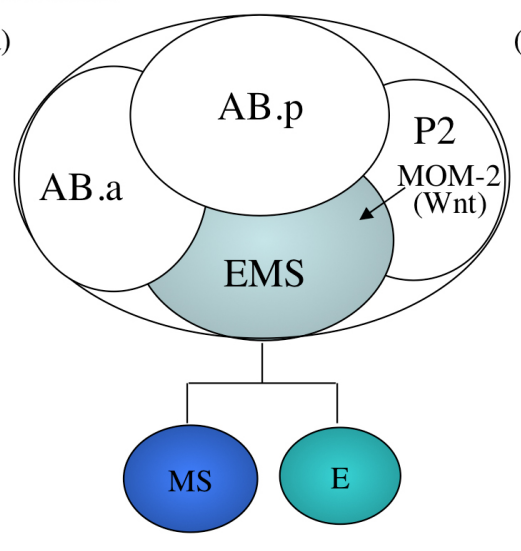

(b)

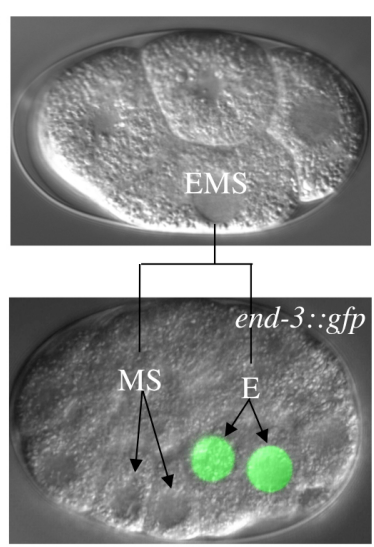

(B) anterior

(a)

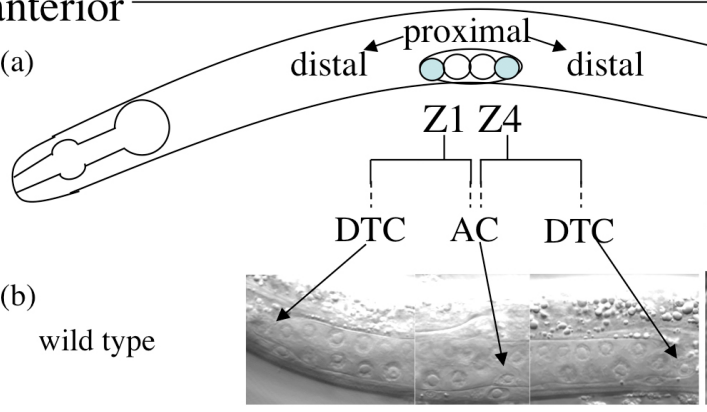

(c)

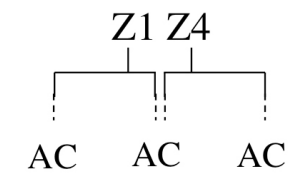

hypodermal neural

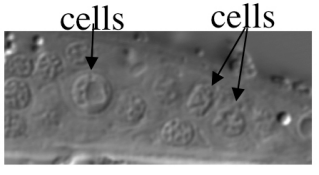

wrm- 1 mutant

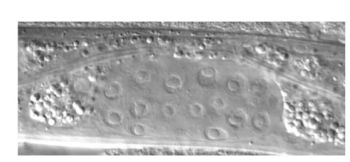

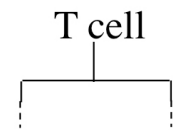

hypodermal hypodermal

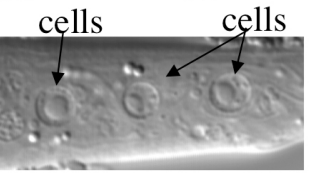

Figure 5. Asymmetric cell division regulated by the Wnt/ $\beta$-catenin asymmetry pathway. Asymmetric EMS division in the 4-cell embryo. MOM-2 (Wnt) polarizes the EMS cell, which divides into the anterior MS blastomere, a mesoderm precursor, and the posterior E blastomere, which produces the endoderm (a). DIC images of EMS and its granddaughters (daughters of the E blastomere, which express end-3::gfp [26, 55]), are shown in (b). (B) SGP (Z1/Z4) and T cell divisions during post-embryonic development. (a) Positions of the Z1/Z4 and T cells in the L1 larva. The position of LIN-44 (Wnt)-expressing cells is indicated in red. (b) Asymmetric Z1/Z4 and T cell divisions in wild-type animals. The distal daughters of the SGPs generate DTCs, which guide elongation of the gonad, whereas the proximal daughters produce the anchor cell (AC), which induces formation of the vulva. The anterior daughter of the T cell produces hypodermal cells, and the posterior daughter generates neural cells. (c) Symmetric divisions in wrm-1 ( $\beta$-catenin) mutants. The gonad fails to elongate because of the loss of DTCs (the Sys phenotype). The posterior T cell daughters adopt a hypodermal fate instead of the neuronal fate (the Psa phenotype). Anterior is toward the left, and ventral is toward the bottom. Reprinted with permission from (Mizumoto and Sawa, 2007).

Although this pathway involves components of the canonical Wnt pathway, including two $\beta$-catenins (WRM-1 and SYS-1), it is categorized as a divergent canonical pathway because of its unique regulation, which involves the asymmetric localizations of signaling components rather than the stabilization of $\beta$-catenin (Figure 6). During cell division, Frizzled (Fz) proteins (MOM-5 in embryonic cells and LIN-17 in the T cell) (Goldstein et al., 2006; Park et al., 2004) and Dishevelled (DSH) proteins (DSH-2 and MIG-5 in EMS, T, and seam cells) (Mizumoto and Sawa, 2007; Walston et al., 2004) localize to the posterior cortex, while WRM-1/ $\beta$-catenin, APR-1/APC, PRY-1/Axin, and LIT-1/NLK kinase localize to the anterior cortex (Nakamura et al., 2005; Takeshita and Sawa, 2005). At telophase, two $\beta$-catenins, WRM-1 and SYS-1, as well as LIT-1 start to localize preferentially to the posterior nucleus (Huang et al., 2007; Lo et al., 2004; Nakamura et al., 2005; Phillips et al., 2007; Takeshita and 
Sawa, 2005), while POP-1/TCF is predominantly in the anterior nucleus (POP-1 asymmetry) (Lin et al., 1998; Lin et al., 1995). In addition to the EMS and T cell divisions, asymmetric localizations, particularly at the nucleus, occur during cell divisions in many different lineages during embryonic and postembryonic stages. Furthermore, some of the components, especially LIT-1 and POP-1, are required in most asymmetric cell divisions in C. elegans to correctly specify the fates of the progeny (Kaletta et al., 1997; Lin et al., 1998). Therefore, similar mechanisms are thought to operate in most somatic cell divisions that generate different daughter cells.

(a)
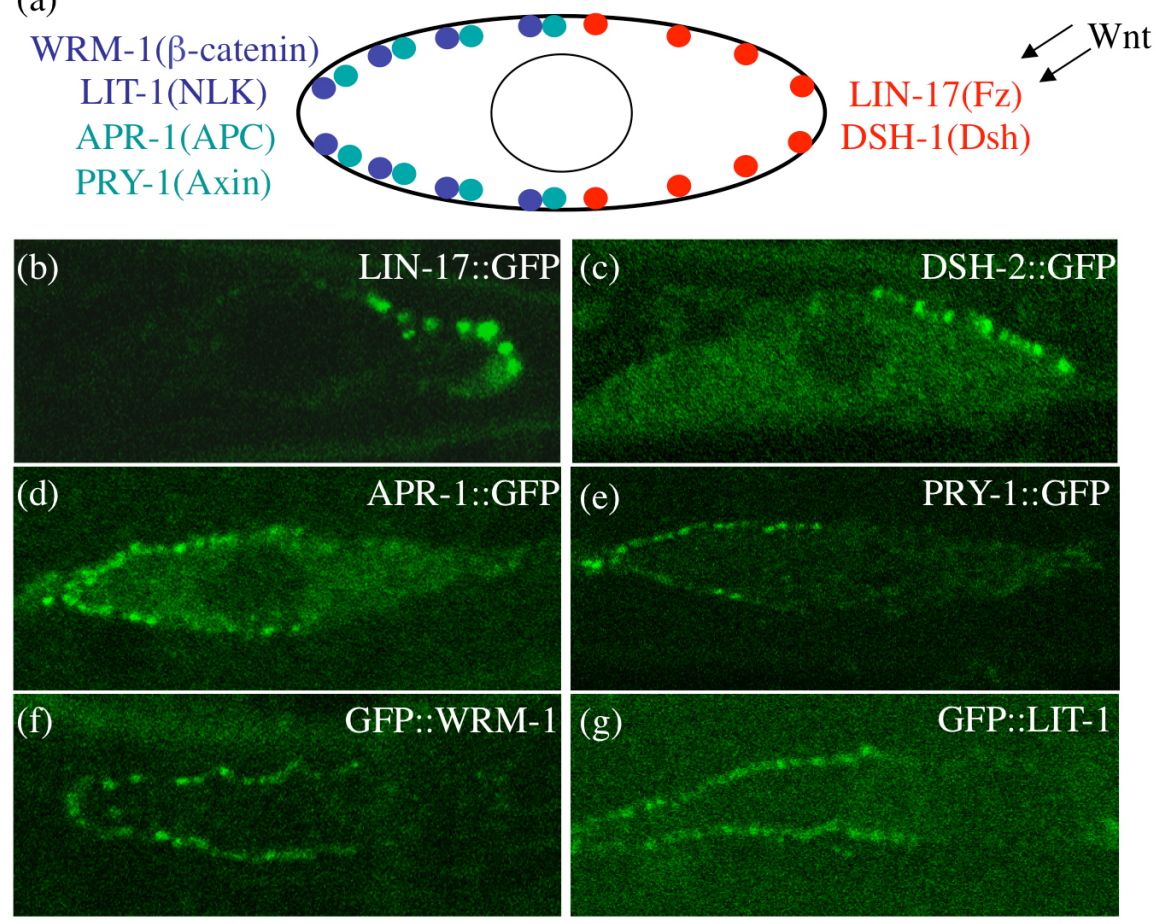

(h)
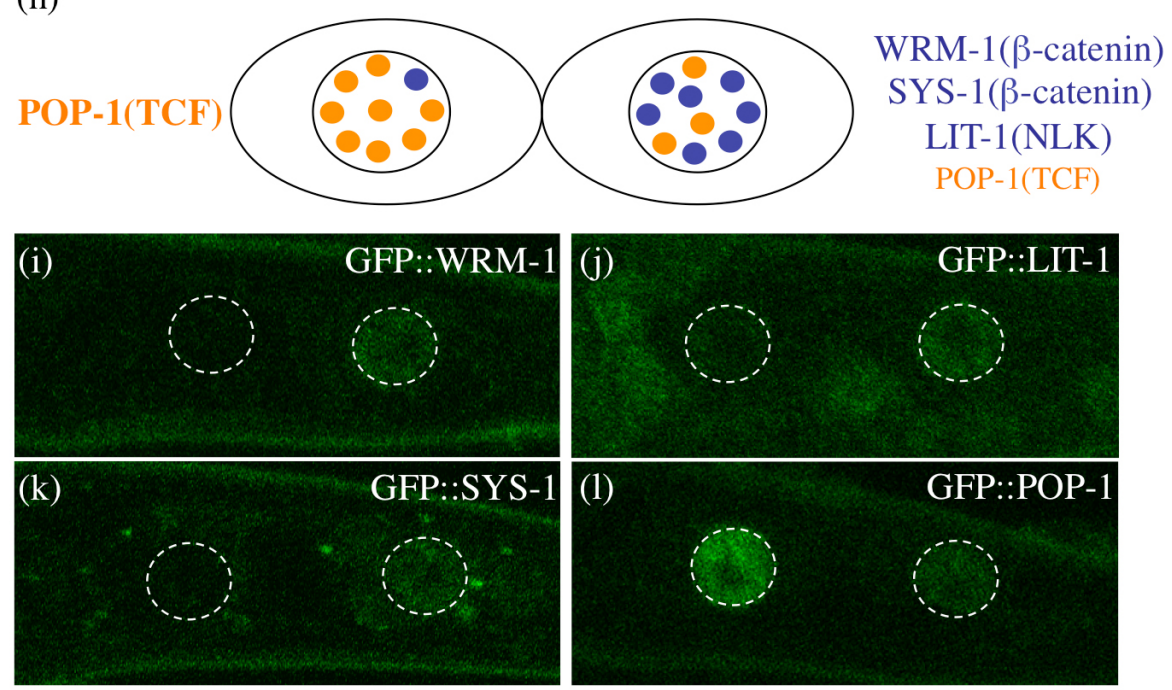

Figure 6. Asymmetric localization of components of the Wnt/B-catenin asymmetry pathway in seam cells. (a), (h) Schematic summaries of the localization patterns of components of the Wnt/ $\beta$-catenin asymmetry pathway prior to (a) or after (h) seam-cell division. (b-g) and (i-1) are confocal images of their localizations. In seam cells, LIN-17 (Fz) (b) and DSH-2 (Dsh) (c) localize to the posterior cortex, and APR-1 (APC) (d), PRY-1 (Axin) (e), WRM-1 ( $\beta$-catenin) (f), and LIT-1 (NLK) (g) are in the anterior cortex. After the asymmetric cell divisions, WRM-1 (i), LIT-1 (j), and SYS-1 ( $\beta$-catenin) (k) localize to the nucleus of the posterior daughter, whereas POP-1 (1) is more concentrated in the nucleus of the anterior daughter. (b-c) and (i-1) are the T cell, and (d-g) are the V5.p cell. The shapes of the nuclei are indicated by dotted lines in (i-1). Anterior is toward the left, and ventral is toward the bottom. Reprinted with permission from (Mizumoto and Sawa, 2007). 


\subsection{Roles of Wnt proteins in polarity orientation}

The polarity of the EMS blastomere is lost in mom-2/Wnt mutants, resulting in symmetric POP-1 localization and the loss of the endoderm fate (Rocheleau et al., 1997; Thorpe et al., 1997). On the other hand, other cells in Wnt mutants often show polarity reversal, rather than polarity loss. In the AB lineage in embryos, after the fourth division, POP-1 becomes asymmetrically localized (POP-1 asymmetry) so that it is higher in the anterior daughter nuclei, and this asymmetry is often reversed in mom-2 mutants (Park and Priess, 2003; Park et al., 2004). During postembryonic development, the polarity of the T and V5 cells is frequently reversed in lin-44/Wnt and egl-20/Wnt mutants, respectively (Herman et al., 1995; Whangbo et al., 2000). Furthermore, the polarity of other seam cells (V1-V4 and V6) is controlled redundantly by multiple Wnt genes (lin-44, cwn-1, cwn-2 and egl-20) (Yamamoto et al., 2011). Therefore, Wnts have important functions in determining polarity orientation.

At least for some cells, Wnts can instruct the polarity orientation by functioning as positional cues. The MOM-2, LIN-44, and EGL-20 Wnts instructively determine the polarity orientation for the EMS, T and P7.p cells, respectively, when these Wnts are expressed close to the target cells (Goldstein et al., 2006; Green et al., 2008). In the P7.p VPC case, EGL-20 and MOM-2+LIN-44 that are expressed anteriorly (near the anus) and posteriorly (in the anchor cell) to the cell, respectively, promote its polarity in the opposite orientations, suggesting that LIN-44+MOM-2 antagonize global polarity oriented by EGL-20 (see Morphogenesis of the vulva and the vulval-uterine connection). Recent genetic analyses have suggested that Wnts can also control cell polarity from a distance. For example, CWN-1 and CWN-2 are respectively expressed posteriorly and anteriorly with regard to the seam cells (V1-V4) (see Section 2) and control the seam cells' polarity orientation. Interestingly, however, these Wnts can rescue the polarity phenotype, even when they are expressed on the opposite side (anteriorly for CWN-2 and posteriorly for CWN-1) (Yamamoto et al., 2011), suggesting a permissive rather than an instructive role in seam cell orientation. It is not yet clear how each Wnt controls the polarity orientation from a distance.

In addition to Wnts, mutants of some Wnt receptors cause polarity reversal with some frequency, consistent with the notion that they mediate functions of Wnts. For example, the polarity of the V1 seam cell is reversed in cam-1/Ror (a non-Fz type Wnt receptor with a tyrosine kinase domain) or mom-5/Fz mutants (Forrester et al., 1999; Yamamoto et al., 2011). The T cell polarity can be reversed in lin-17/Fz mutants, although loss of polarity is a more frequent outcome (Goldstein et al., 2006).

In addition, Wnt receptors are essential for cell polarization itself, since the polarity of embryonic cells and postembryonic seam cells is lost in mom-5 single and lin-17 mom-5; cam-1 triple mutants, respectively. Since no such phenotype is observed in mom-2 embryos (Lin et al., 1998; Park and Priess, 2003) or in seam cells with mutations in all five Wnt genes (quintuple Wnt mutants) (Yamamoto et al., 2011), Wnt receptors might have some Wnt-independent roles in cell polarization.

Although Wnts are involved in many asymmetric divisions, those of the SGPs (somatic gonadal precursors; $\mathrm{Z1}$ and Z4 cells) (Figure 5B) appear to be Wnt independent, since their polarity is not affected in quintuple Wnt mutants (Yamamoto et al., 2011). The polarities of Z1 and Z4 are mirror symmetric, so that their proximal daughters have the higher levels of POP-1. Although this proximal-distal polarity of POP-1 is not affected in quintuple Wnt mutants, it is disrupted in animals whose germ cells that normally reside between Z1 and Z4 have been ablated. Therefore, SGP polarity is probably regulated by non-Wnt signals from germ cells, although possible functions of mom-2 expressed in germ cells were not eliminated, since a temperature-sensitive mom- 2 mutation was used for quintuple Wnt mutants.

In addition to the orientation of POP-1 asymmetry, Wnts are also required for proper spindle orientation (Bischoff and Schnabel, 2006; Schlesinger et al., 1999; Walston and Hardin, 2006; Wildwater et al., 2011). In the EMS division, MOM-2 orients the spindle by a mechanism involving MOM-5/Fz and DSH proteins. Although the inhibition of GSK-3 kinase causes spindle-orientation defects in EMS (Schlesinger et al., 1999), the role of GSK-3 remains obscure. GSK-3 regulates OMA-1 (CCCH-type zinc finger protein) degradation in the oocyte-to-embryo transition, and the EMS spindle defects in gsk-3 mutants can be rescued by reducing the OMA-1 level, suggesting that the EMS defect may be an indirect consequence of earlier events (Shirayama et al., 2006).

EMS spindle regulation also requires MES-1-SRC-1 signaling, which also functions in the spindle orientation of the P2 cell (Arata et al., 2010; Bei et al., 2002; Berkowitz and Strome, 2000). MES-1 is a transmembrane protein that probably functions in both P2 and EMS through its homophilic interactions. In contrast, SRC-1 kinase functions cell autonomously in the EMS blastomere. MES-1-SRC-1 signaling also regulates POP-1 asymmetry redundantly with Wnt signaling. It is not known, however, how the MES-1-SRC-1 signaling converges with the Wnt pathway. 


\subsection{Establishment of cortical asymmetry}

Wnts and Frizzleds are required for the proper cortical asymmetry of the DSH, WRM-1, LIT-1, and APR-1 proteins, at least in some cells (MOM-2 in the EMS, LIN-44 in the T, and EGL-20 in the V5 cell) (Mizumoto and Sawa, 2007; Nakamura et al., 2005; Sugioka et al., 2011; Takeshita and Sawa, 2005). Since DSHs interact with Fz receptors in other organisms (Wong et al., 2003) and are localized to the posterior cell cortex along with Fz receptors (Mizumoto and Sawa, 2007; Walston et al., 2004), DSHs are likely to be recruited to the posterior cortex by activated $\mathrm{Fz}$ receptors and to regulate the localization of anterior components (e.g., WRM-1, APR-1) to the opposite (anterior) cortex (Movie1). However, the requirement for DSHs in the cortical localizations of other components has not been demonstrated in the $\mathrm{T}$ or seam cells, probably due to redundancy among the three DSHs (DSH-1, DSH-2, and MIG-5).

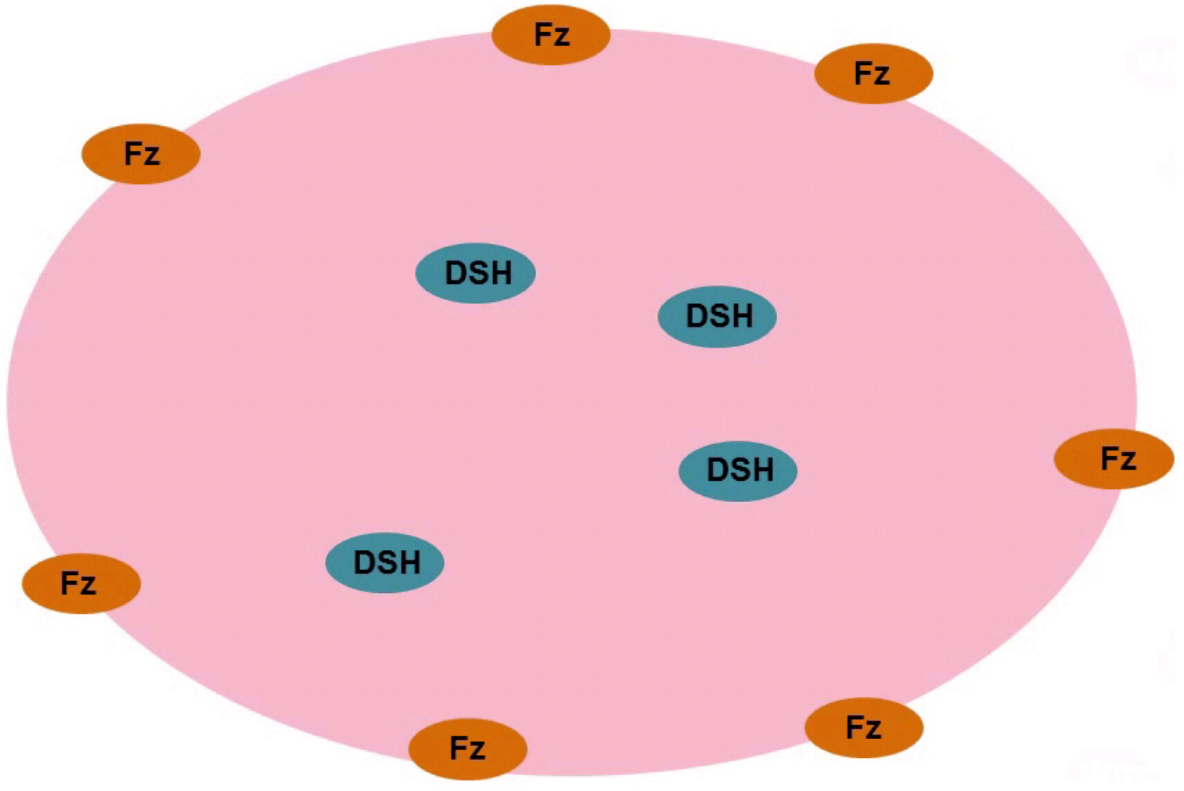

Movie 1. An animated model of asymmetric cell division (see html version of this chapter to view animation). Wnts binds to Fz on the posterior side of cells and induce the accumulation of Fz and DSHs on the posterior cortex. Probably in response to the localization of DSHs, the WRM-1-LIT-1 complex localizes to the anterior cortex and recruits APR-1. At telophase of the division, the cortical APR-1 stabilizes the astral microtubules to create asymmetry in their numbers. The WRM-1-LIT-1 complex can be imported into both daughter nuclei, but its nuclear export is accelerated from the anterior nucleus by the astral microtubules, possibly through its kinesin-dependent transport along the microtubules toward the cell cortex. SYS-1 is destabilized in the anterior daughter cell and accumulates in the posterior nucleus. In the posterior nucleus, POP-1 binds either to SYS-1 or WRM-1. When it binds to WRM-1, it is phosphorylated by LIT-1, which induces its release from the WRM-1-LIT-1 complex and export out of the nucleus through the function of PAR-5 (not shown in the movie), which binds to phosphorylated POP-1. POP-1 that binds to SYS-1 cannot bind to WRM-1 and stays in the nucleus.

In SGPs and embryonic cells, DSH-2 is required for the nuclear asymmetry of POP-1, which is presumably regulated by the cortical asymmetries of WRM-1 and APR-1 (see below) (King et al., 2009; Phillips et al., 2007). Among the components localized to the anterior cortex, WRM-1 appears to function most upstream, since it is required for the localization of APR-1 (Mizumoto and Sawa, 2007; Sugioka et al., 2011). However it remains a mystery how WRM-1 localizes to the cortex, since WRM-1/ $\beta$-catenin does not bind to HMR-1/cadherin (Korswagen et al., 2000; Natarajan et al., 2001).

\subsection{Regulation of nuclear asymmetry}

The nuclear asymmetry of WRM-1 is regulated by WRM-1 on the anterior cortex, since the forced uniform localization of WRM-1 throughout the cortex results in symmetric WRM-1 nuclear localization (Mizumoto and Sawa, 2007). The effect of cortical WRM-1 is mediated by APR-1 and microtubules, at least in the division of EMS (Movie1) (Sugioka et al., 2011). At telophase, APR-1 on the anterior cortex binds and stabilizes microtubules to create an asymmetry in the number of astral microtubules. Manipulating this spindle-microtubule asymmetry by laser irradiation showed that it is essential for the nuclear asymmetries of WRM-1 and POP-1. However, how the spindle asymmetry controls nuclear localizations remains to be elucidated. 
After its entry into the nucleus, WRM-1 regulates POP-1 asymmetry (Movie1). WRM-1 binds to and activates LIT-1 kinase, which is also localized to the posterior nucleus (Lo et al., 2004). The activated LIT-1-WRM-1 complex phosphorylates POP-1 through a direct interaction between WRM-1 and POP-1 (Yang et al., 2011). The phosphorylated POP-1 is released from the LIT-1-WRM-1 complex and binds to PAR-5/14-3-3, which mediates the nuclear export of POP-1 from the posterior nucleus, resulting in POP-1 asymmetry (higher in the anterior daughter) that is reciprocal to the nuclear asymmetry of WRM-1 and LIT-1 (higher in the posterior daughter).

Another $\beta$-catenin-like protein, SYS-1, also localizes asymmetrically to the nucleus of the posterior daughter in the EMS division and to that of the distal daughters in the SGP divisions, as does WRM-1 (Huang et al., 2007; Phillips et al., 2007). This asymmetry was shown to require Wnt (in the EMS), Frizzled (in both), DSH-2 (in SGPs), and APR-1 (in the EMS), but not WRM-1 or LIT-1. Since the cortical localization of APR-1 is regulated by WRM-1, cytoplasmic rather than cortical APR-1 is likely to regulate SYS-1 asymmetry. Interestingly, in the SGPs, SYS-1 is symmetric during division, but is lost in the proximal daughters after division, suggesting that it is degraded (Phillips et al., 2007). Consistently, SYS-1 asymmetry in the EMS division is disrupted by the inhibition of proteasome components (Huang et al., 2007). These observations raise the interesting possibility that SYS-1 is regulated at the level of protein stability (Movie1), as is $\beta$-catenin in other organisms, even though SYS-1 (like WRM-1) does not have the conserved phosphorylation sites for GSK-3 $\beta$ kinase that are required for the degradation of $\beta$-catenin in other organisms. In any case, the asymmetric nuclear localizations of two $\beta$-catenin homologs, WRM-1 and SYS-1, are regulated through distinct mechanisms.

\subsection{Asymmetric fate specification}

SYS-1 has no significant sequence similarity to the $\beta$-catenin of other organisms. Nonetheless, it is considered one of the four homologs of $\beta$-catenin in C. elegans (SYS-1, WRM-1, BAR-1, and HMP-2). This is because SYS-1 can bind to POP-1/TCF to activate transcription in mammalian cells (Kidd et al., 2005), while WRM-1 has only limited co-activator activity (Korswagen et al., 2000; Natarajan et al., 2001), and most-importantly, the crystal structure of SYS-1 resembles that of $\beta$-catenin (Liu et al., 2008). Therefore, the Wnt/ $\beta$-catenin asymmetry pathway controls the reciprocal asymmetry of the nuclear localizations of POP-1 and its co-activator SYS-1.

Given the phenotypes of sys- 1 loss-of-function or overexpression mutants, asymmetric cell fates have been proposed to be determined by the balance between nuclear POP-1 and its co-activator SYS-1 (Kidd et al., 2005). In the anterior daughters (distal daughters for SGPs), which have high POP-1 and low SYS-1, most POP-1 is not bound to SYS-1, and POP-1 functions as a transcriptional repressor. In contrast, in the posterior daughters (proximal daughters for SGPs), the high level of SYS-1 is more than sufficient to bind the low amount of POP-1, converting it to a transcriptional activator. This difference in the balance of these molecules thus results in the asymmetric expression of POP-1 target genes (described below) between the daughter cells, effectively converting the nuclear asymmetry of proteins to asymmetric fates in the daughter cells.

To elicit the functions of POP-1, additional transcription factors are also required. In EMS division, the histone deacetylase HDA-1 and UNC-37/Groucho function as co-repressors with POP-1 to block end-1 expression in the MS daughter, and CBP-1 is required for POP-1 to activate end-1 (Calvo et al., 2001). In the T cell daughters, two chromatin-remodeling complexes, $\mathrm{CeBAF}$ and $\mathrm{CePBAF}$, and the transcriptional Mediator complex regulate the asymmetric expression of psa-3 and/or tlp-1 (Sawa et al., 2000; Shibata et al., 2012; Yoda et al., 2005; Zhao et al., 2002). It is not known, however, how widely these transcription factors function with POP-1 in other asymmetric divisions.

After the asymmetric divisions, POP-1 appears to regulate distinct target genes, depending on the cell type. After the EMS division, POP-1 directly represses and activates the expression of end-1 in the anterior MS and posterior E daughters, respectively (Maduro et al., 2002; Shetty et al., 2005). In the distal daughter of SGP and the posterior daughter of the T cell, POP-1 respectively activates ceh-22 and psa-3 directly (Arata et al., 2006; Lam et al., 2006). Cell-specific transcription factors or their combinations are proposed to regulate the specificity of the POP-1 targets (Bertrand and Hobert, 2009; Lin et al., 1998). Indeed, in the T cell and a neuroblast (the SMDD/AIY mother), POP-1 cooperates with the cell-specific transcription factors NOB-1/Hox and TTX-3, respectively, to directly activate cell-specific target genes (Arata et al., 2006; Bertrand and Hobert, 2009). 
It is not known, however, whether such cell-specific factors exist in all the cell types in which POP-1 functions. The involvement of chromatin modifiers and the histone-binding protein BET-1 in establishing and maintaining, respectively, the asymmetry of the $\mathrm{T}$ cell daughter fates suggests that epigenetic regulation might be involved in the cell-specific selection of POP-1 targets (Sawa et al., 2000; Shibata et al., 2010; Shibata et al., 2012).

\section{Non-canonical Wnt signaling controls neuroblast migration along the anteroposterior axis}

Wnt signaling controls the migration of the HSN, ALM, CAN and BDU neurons during embryogenesis and the migration of the QL and QR descendants during early larval development (Figure 7) (Hedgecock et al., 1987; Sulston and Horvitz, 1977). With the exception of QL descendant migration, signaling is mediated through $\beta$-catenin independent, non-canonical Wnt signaling mechanisms that are still poorly understood (Silhankova and Korswagen, 2007). A general theme that emerges from the studies of these different neuronal migrations is that a combinatorial activity of multiple Wnts and Wnt receptors is required to guide the cells to their final positions.

Embryonic migrations

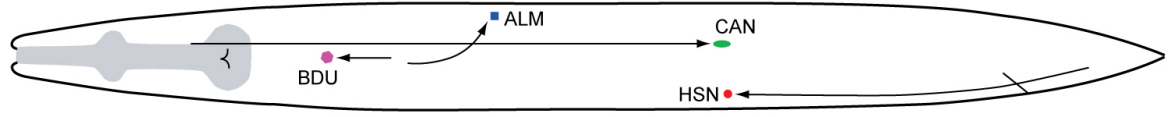

Post-embryonic migrations

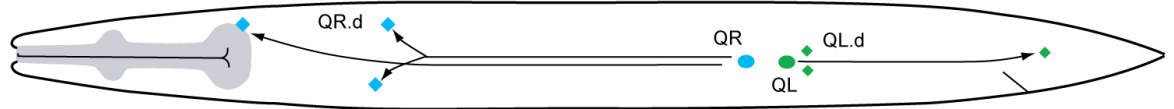

Figure 7. Wnt dependent cell migrations. Schematic representation of the embryonic and post-embryonic cell migrations that are controlled by Wnt signaling. (Green and blue ovals represent QL and QR and the diamonds the QL and QR descendants, abbreviated as QL.d and QR.d)

\subsection{HSN migration: function of EGL-20 as a repulsive guidance cue}

The HSN neurons migrate during embryogenesis from the tail to a well defined position just posterior to the developing gonad in the mid-body region (Hedgecock et al., 1987; Sulston and Horvitz, 1977). HSN migration is dependent on EGL-20, but mutations in the four other Wnts significantly enhance the migration phenotype of egl-20 null mutants, indicating that they play a minor role as well (Pan et al., 2006; Zinovyeva et al., 2008). In an elegant set of experiments, it has been shown that the posteriorly expressed EGL-20 acts as a repulsive cue that drives HSN migration towards the anterior (Pan et al., 2006). Migration terminates when the HSN neuron reaches a position close to the CAN neuron (Forrester and Garriga, 1997). The CAN cell expresses CAM-1, an ortholog of the non-canonical Wnt receptor Ror, and may block HSN migration by acting as a sink for EGL-20 (Forrester et al., 2004; Kim and Forrester, 2003; Pan et al., 2006). The main Wnt receptor required for HSN migration is the Frizzled mig- 1 , but other Frizzled receptors appear to have a minor contribution as well. Interestingly, the mig- 1 induced defect in HSN migration is suppressed by mutation of lin-17/Fz.

\subsection{Migration of the $Q R$ descendants}

The QR descendants migrate from a position close to the seam cell V4 in the mid body region to well defined positions in the anterior, where they differentiate into the neurons AQR, SDQR, and AVM (Hedgecock et al., 1987; Sulston and Horvitz, 1977). In egl-20, cwn-1, and cwn-2 mutants, the QR descendants migrate less far, an undermigration that is most severe in egl-20; cwn-1 and $c w n-1 ; c w n-2$ double mutants and in mutants in which all five Wnt genes are disrupted (Harris et al., 1996; Zinovyeva et al., 2008). At the level of Wnt receptors, there is clear undermigration in mom-5/Fz mutants, a phenotype that is strongly enhanced in mom-5; cfz-2 and mom-5; lin-17 double mutants or a quadruple mutant in which all Frizzled receptors are mutated (Zinovyeva et al., 2008). The migration of the QR descendants also requires CAM-1, a function that at least partially depends on CAM-1 kinase activity (Kim and Forrester, 2003). 


\subsection{Migration of the BDU neurons}

The BDU neurons migrate a short distance towards the anterior during embryogenesis (Hedgecock et al., 1987; Sulston and Horvitz, 1977). BDU migration requires the Wnts CWN-1 and CWN-2 and the Frizzleds MOM-5 and LIN-17 (Zinovyeva et al., 2008). The BDU neurons migrate too far in mutants of cam-1/Ror (Forrester et al., 1999).

\subsection{Migration of the CAN neurons}

The CAN neurons migrate during embryogenesis from a position in the head to a well defined position in the mid body (Hedgecock et al., 1987; Sulston and Horvitz, 1977). The main Wnt required for CAN cell migration is CWN-2, with additional functions for CWN-1 and EGL-20 that become evident in double mutant combinations with cwn-2 (Zinovyeva and Forrester, 2005; Zinovyeva et al., 2008). The principle receptor is MOM-5/Fz, with a minor role for the Frizzled CFZ-2. The Ror ortholog CAM-1 is also required for CAN cell migration, a function that appears to be independent of its kinase activity (Forrester and Garriga, 1997; Kim and Forrester, 2003).

\subsection{Migration of the ALM neurons}

The posterior migration of the ALM neurons (Hedgecock et al., 1987; Sulston and Horvitz, 1977) is dependent on the partially redundantly acting Wnts CWN-1 and CWN-2 and requires the receptor CFZ-2/Fz, with a possible antagonistic function of MOM-5/Fz and LIN-18/Ryk (Zinovyeva et al., 2008).

\section{Various effects of Wnt signaling on the development and function of the nervous system}

In addition to the roles of Wnt signaling in the migration of neurons and neuroblasts described above, a number of reports describe the role of Wnt signaling in the development and function of the nervous system in $C$. elegans. Consistent with this, quintuple Wnt mutants are nearly paralyzed (H. Sawa, unpublished observation), suggesting that Wnt signaling plays a profound role in the nervous system. Interestingly, the effects of Wnt signaling vary depending on the neuronal type.

\subsection{Function of Wnts in neurite growth}

The anterior extension of the AVM and PVM processes is redundantly regulated by CWN-1 and EGL-20 (Pan et al., 2006). In cwn-1; egl-20 double mutants, the AVM and PVM processes show a variety of defects, including premature termination, ectopic branching, and posterior extension (Figure 8A for PVM). EGL-20 appears to function as a repellant for these processes, since its local expression in head neurons or its uniform expression using the heat-shock promoter causes misrouting of the processes, while its expression in the posterior region rescues the guidance defect in cwn-1; egl-20 double mutants. Wnt receptors MIG-1/Fz, MOM-5/Fz, and LIN-18/Derailed (only for PVM) are required for this regulation. 
A

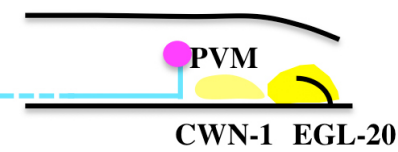

B

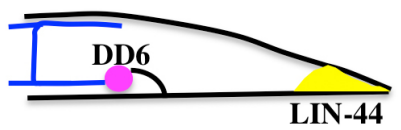

C

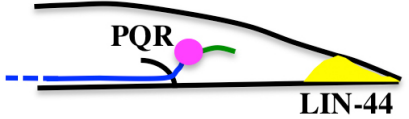

D

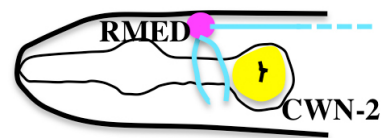

E

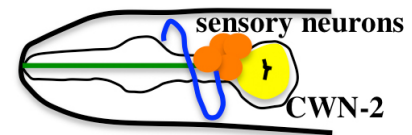

F

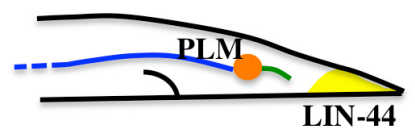

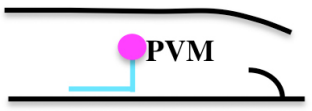
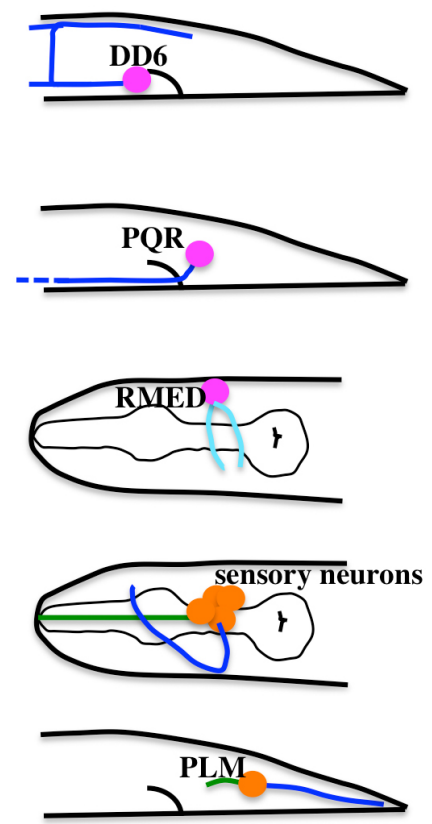

G
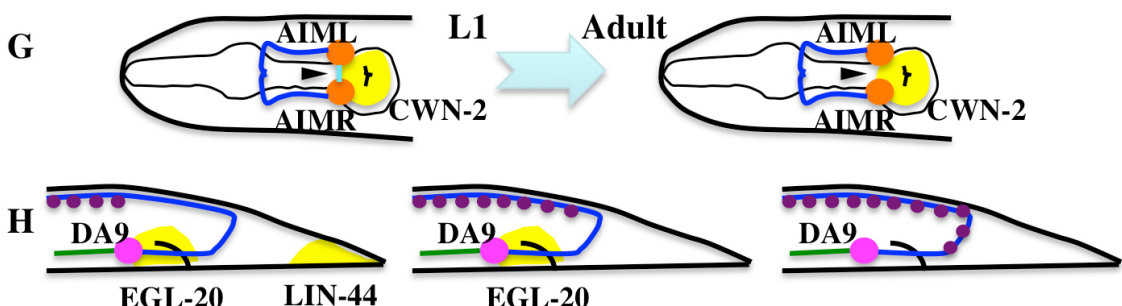

EGL-20

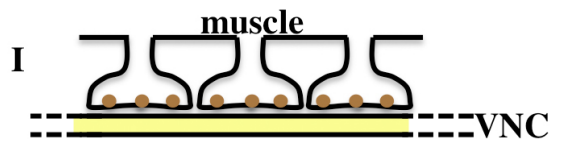

CWN-2

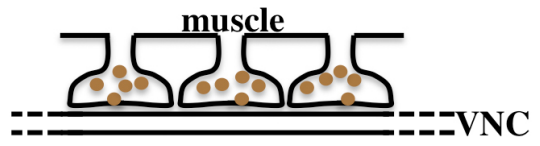

Figure 8. Various effects of Wnt signaling on the nervous system. Schematic representations of the nervous system and its defects in Wnt mutants. Blue, green, and light blue lines represent axons, dendrites, and neurites, respectively. Arrowheads in $\mathrm{G}$ indicate a neurite eliminated during larval development. This process is accelerated in $c w n-2$ mutants. Purple and brown circles in $\mathrm{H}$ and I represent synapses and acetylcholine-gated ion channels, respectively. VNC stands for ventral nerve cord. Wnt expressions are roughly shown in yellow (See text for details). The effects of Wnts are instructive for neurons (magenta cell bodies) or permissive for neurons (orange cell bodies). Left and right panels represent wild type and Wnt mutants, respectively, except for $\mathrm{G}$ and $\mathrm{H}$. In $\mathrm{G}$, the left and right panels represent $\mathrm{L} 1$ and adult wild-type animals. In $\mathrm{H}$, the left, middle, and right panels represent wild type, lin-44, and lin-44; egl-20 mutants, respectively. Panel I represents a much higher magnification compared to the other panels.

Similarly, LIN-44 functions as a repellant of axon growth (Maro et al., 2009). A neural process of the GABAergic DD6 motoneuron on the dorsal side, which extends posteriorly, normally terminates at about the same anteroposterior position as is occupied by its ventral cell body (Figure 8B, left). In lin-44 mutants, the axon overextends posteriorly (Figure 8B, right). In animals expressing lin-44 ectopically in the anterior region, the processes are under-extended. These data suggest that LIN-44 functions as a guidance cue that repels the axon.

In contrast to its repulsion of the DD6 axon, LIN-44 functions as a dendrite attractant for the oxygen-sensory neuron PQR, which is born during the L1 stage (Kirszenblat et al., 2011). In mutants of LIN-44 or its receptor 
LIN-17/Fz, the posteriorly oriented dendrite of PQR is short, absent, or misrouted anteriorly (Figure 8C). Since the anterior expression of LIN-44 in lin-44 mutants enhances the anterior mis-routing phenotype, LIN-44 attracts the $\mathrm{PQR}$ dendrite. Surprisingly, ablation of all the LIN-44-expressing cells in the tail of newly hatched L1 larvae, before the production of $\mathrm{PQR}$, does not affect the $\mathrm{PQR}$ dendrite, suggesting that the distribution of LIN-44 during embryogenesis persists and is sufficient to guide the PQR dendrite in larvae.

Similar to the attraction of the PQR dendrite by LIN-44, CWN-2 functions as an attractant for the posteriorly extending process of the GABAergic neurons RMED/V (Figure 8D, left) (Song et al., 2010). Most cwn-2 mutants lack this neural process (Figure 8D, right). CWN-2 is expressed strongly in the posterior pharyngeal bulb, and its ectopic expression anterior to the RMED/V cell bodies in cwn-2 mutants can cause anterior extension of the processes. CWN-2 acts through two redundant Fz receptors (MIG-1 and CFZ-2) and CAM-1/Ror. The signal is transmitted through DSH-1, which binds directly to CAM-1, at least in the yeast two-hybrid assay.

CWN-2 also controls the position of the nerve ring, a sensory axon bundle (Kennerdell et al., 2009). In cwn-2 mutants, the nerve ring and the cell bodies of its surrounding neurons shift anteriorly (Figure 8E). Although CWN-2 is expressed strongly in the posterior pharyngeal bulb, an ideal position for it to repel the nerve-ring axons, CWN-2 actually functions as a permissive signal, since its ectopic expression anterior to the nerve ring can rescue the nerve ring defect of cwn-2 mutants. As in RMED/V, CAM-1 and MIG-1 function as receptors of CWN-2 for the nerve-ring positioning. Since CAM-1 is required in the SIA and SIB neurons, whose ablation causes nerve-ring defects, CWN-2 may directly affect the axons of these neurons, which in turn instruct the positioning of the nerve ring.

\subsection{Regulation of neuronal polarity by Wnts}

The PLM neuron has a long anteriorly extending axon and a short posteriorly extending dendrite (Figure 8F, left). This polarity is reversed in lin-17 or lin-44-mutants, in which it has a short anterior dendrite and a posteriorly extending axon (Figure 8F, right) (Hilliard and Bargmann, 2006; Prasad and Clark, 2006). LIN-44 is a permissive signal, since its anterior or uniform expression can rescue the phenotype. LIN-17 is localized to the posteriorly extending dendrite in a lin-44-dependent manner. Similarly, ALM's polarity is redundantly regulated by CWN-1, CWN-2, and EGL-20. In contrast to PLM, a strong uniform expression of EGL-20 in wild-type causes an ALM polarity defect, indicating that EGL-20 might function as a positional cue.

\subsection{Wnts inhibit neurite elimination}

The medially projected neurite of AIM (Arrowheads in Figure 8G) is eliminated in about $90 \%$ of wild-type animals during larval development. This process is accelerated and enhanced in cam-1, cwn-1, cwn-2, or vang-1/Nan Gogh (a putative component of the PCP pathway) mutants, indicating that the Wnt signals inhibit neurite elimination (Hayashi et al., 2009). CWN-1 and CWN-2 function redundantly, probably as permissive signals, since their expression in all neurons or pharyngeal muscle rescues the mutant phenotype.

\subsection{Wnts regulate synaptic positions}

In contrast to the cases described above, in the DA9 motoneuron, Wnts regulate the positions of synapses without affecting the axon or dendrite morphology (Klassen and Shen, 2007). The presynaptic positions of DA9 are restricted to a specific segment through the functions of LIN-44 and EGL-20. In lin-44 mutants, the synaptic domain is expanded posteriorly (Figure $8 \mathrm{H}$ ). Although an egl-20 mutation by itself has only a subtle effect, in egl-20 lin-44 double mutants, the synaptic domain is further expanded to the commissure. The ectopic expression of LIN-44 causes the elimination of nearby synapses, suggesting that LIN-44 instructively inhibits presynaptic assembly. LIN-44 acts through the LIN-17 receptor, at least in part by regulating its localization to the posterior asynaptic domain. DSH-1 functions downstream of LIN-17 to inhibit synapse formation.

\subsection{Wnt signaling regulates synaptic plasticity}

In addition to regulating the development of the nervous system, Wnt signaling also modulates the function of the nervous system by regulating the translocation of a post-synaptic acetylcholine receptor (AChR) in the body wall muscles (Figure 8I). In mutants of cwn-2, cam-1, lin-17, or dsh-1, an AChR (ACR-16) accumulates in the subsynaptic region of muscle arms, while its localization to the postsynaptic surface is reduced (Jensen et al., 2012). This results in reduced acetylcholine-gated current and locomotion defects. The expression of CWN-2 in neurons or muscle rescues the behavioral defects of $c w n-2$ mutants, while a tissue-specific RNAi of $c w n-2$ in neurons but not in 
muscle causes the defects and the aberrant localization of ACR-16. In contrast, LIN-17 and DSH-1 are required in muscle but not in neurons. When CWN-2::GFP is expressed in motoneurons, the GFP fluorescence is decreased upon depolarization of the neurons in a mig-14/Wntless-dependent manner. These results suggest that neuronal activation leads to the secretion of $\mathrm{CWN}-2$ from motor neurons, which then increases the acetylcholine-gated current by mediating the translocation of ACR-16 to the post-synaptic surface of the muscle arms.

\section{Summary and perspective}

Wnt signaling regulates diverse biological processes, including cell differentiation, migration, asymmetric cell division, and neural development. Currently, how such diverse responses are produced is not clear. Even a single Wnt acts differently depending on the cell type. For example, EGL-20 activates the canonical pathway in QL.d migration, the non-canonical pathway in QR.d migration and the Wnt/ $\beta$-catenin asymmetry pathway in seam cells. The difference in signaling response may be determined by the collection of Wnt receptors that a cell expresses. In mammalian cells, for example, expression of the Wnt co-receptor LRP5/6 leads to activation of canonical Wnt/ $\beta$-catenin signaling (Angers and Moon, 2009). Interestingly, it appears that $C$. elegans does not have a clear LRP5/6 ortholog, raising the question of how signaling specificity is achieved. An important direction for future research will be to determine how Wnts and their Frizzled, CAM-1/Ror and LIN-18/Ryk receptors activate such a wide range of signaling responses.

\section{Acknowledgements}

We thank Kota Mizumoto, Remco Mentink, and Teije Middelkoop for comments on the manuscript. This work was supported by Grants-in-Aid for Scientific Research from the Ministry of Education, Culture, Sports, Science, and Technology of Japan to H. S. and the Dutch Cancer Society (HUBR 2008-4114) to H.C.K.

\section{References}

Angers, S., and Moon, R.T. (2009). Proximal events in Wnt signal transduction. Nat. Rev. Mol. Cell Biol. 10, 468-477. Abstract Article

Arata, Y., Kouike, H., Zhang, Y., Herman, M.A., Okano, H., and Sawa, H. (2006). Wnt signaling and a Hox protein cooperatively regulate $p s a-3 /$ Meis to determine daughter cell fate after asymmetric cell division in $C$. elegans. Dev. Cell 11, 105-115. Abstract Article

Arata, Y., Lee, J.Y., Goldstein, B., and Sawa, H. (2010). Extracellular control of PAR protein localization during asymmetric cell division in the C. elegans embryo. Development 137, 3337-3345. Abstract Article

Banerjee, D., Chen, X., Lin, S.Y., and Slack, F.J. (2010). kin-19/casein kinase I $\alpha$ has dual functions in regulating asymmetric division and terminal differentiation in C. elegans epidermal stem cells. Cell Cycle 9, 4748-4765. Abstract Article

Banziger, C., Soldini, D., Schutt, C., Zipperlen, P., Hausmann, G., and Basler, K. (2006). Wntless, a conserved membrane protein dedicated to the secretion of Wnt proteins from signaling cells. Cell 125, 509-522. Abstract Article

Bei, Y., Hogan, J., Berkowitz, L.A., Soto, M., Rocheleau, C.E., Pang, K.M., Collins, J., and Mello, C.C. (2002). SRC-1 and Wnt signaling act together to specify endoderm and to control cleavage orientation in early $C$. elegans embryos. Dev. Cell 3, 113-125. Abstract Article

Belenkaya, T.Y., Wu, Y., Tang, X., Zhou, B., Cheng, L., Sharma, Y.V., Yan, D., Selva, E.M., and Lin, X. (2008). The retromer complex influences Wnt secretion by recycling wntless from endosomes to the trans-Golgi network. Dev. Cell 14, 120-131. Abstract Article

Berkowitz, L.A., and Strome, S. (2000). MES-1, a protein required for unequal divisions of the germline in early $C$. elegans embryos, resembles receptor tyrosine kinases and is localized to the boundary between the germline and gut cells. Development 127, 4419-4431. Abstract 
Bertrand, V., and Hobert, O. (2009). Linking asymmetric cell division to the terminal differentiation program of postmitotic neurons in C. elegans. Dev. Cell 16, 563-575. Abstract Article

Bischoff, M., and Schnabel, R. (2006). A posterior centre establishes and maintains polarity of the Caenorhabditis elegans embryo by a Wnt-dependent relay mechanism. PLoS Biol. 4, e396. Abstract Article

Bovolenta, P., Esteve, P., Ruiz, J.M., Cisneros, E., and Lopez-Rios, J. (2008). Beyond Wnt inhibition: new functions of secreted Frizzled-related proteins in development and disease. J. Cell Sci. 121, 737-746. Abstract Article

Buechling, T., Chaudhary, V., Spirohn, K., Weiss, M., and Boutros, M. (2011). p24 proteins are required for secretion of Wnt ligands. EMBO Rep. 12, 1265-1272. Abstract Article

Cadigan, K.M., and Nusse, R. (1997). Wnt signaling: a common theme in animal development. Genes Dev. 11, 3286-3305. Abstract Article

Calvo, D., Victor, M., Gay, F., Sui, G., Luke, M.P., Dufourcq, P., Wen, G., Maduro, M., Rothman, J., and Shi, Y. (2001). A POP-1 repressor complex restricts inappropriate cell type-specific gene transcription during Caenorhabditis elegans embryogenesis. EMBO J. 20, 7197-7208. Abstract Article

Clevers, H., and Nusse, R. (2012). Wnt/ß-catenin signaling and disease. Cell 149, 1192-1205. Abstract Article

Costa, M., Raich, W., Agbunag, C., Leung, B., Hardin, J., and Priess, J.R. (1998). A putative catenin-cadherin system mediates morphogenesis of the Caenorhabditis elegans embryo. J. Cell Biol. 141, 297-308. Abstract Article

Coudreuse, D.Y., Roel, G., Betist, M.C., Destree, O., and Korswagen, H.C. (2006). Wnt gradient formation requires retromer function in Wnt-producing cells. Science 312, 921-924. Abstract Article

Cullen, P.J., and Korswagen, H.C. (2012). Sorting nexins provide diversity for retromer-dependent trafficking events. Nat. Cell Biol. 14, 29-37. Abstract Article

Dreier, L., Burbea, M., and Kaplan, J.M. (2005). LIN-23-mediated degradation of $\beta$-catenin regulates the abundance of GLR-1 glutamate receptors in the ventral nerve cord of C. elegans. Neuron 46, 51-64. Abstract Article

Eisenmann, D. M., Wnt signaling (June 25, 2005), WormBook, ed. The C. elegans Research Community, WormBook, doi/10.1895/wormbook.1.7.1, http://www.wormbook.org.

Eisenmann, D.M., and Kim, S.K. (2000). Protruding vulva mutants identify novel loci and Wnt signaling factors that function during Caenorhabditis elegans vulva development. Genetics 156, 1097-1116. Abstract

Eisenmann, D.M., Maloof, J.N., Simske, J.S., Kenyon, C., and Kim, S.K. (1998). The $\beta$-catenin homolog BAR-1 and LET-60 Ras coordinately regulate the Hox gene lin-39 during Caenorhabditis elegans vulval development. Development 125, 3667-3680. Abstract

Forrester, W.C., Dell, M., Perens, E., and Garriga, G. (1999). A C. elegans Ror receptor tyrosine kinase regulates cell motility and asymmetric cell division. Nature 400, 881-885. Abstract Article

Forrester, W.C., and Garriga, G. (1997). Genes necessary for C. elegans cell and growth cone migrations. Development 124, 1831-1843. Abstract

Forrester, W.C., Kim, C., and Garriga, G. (2004). The Caenorhabditis elegans Ror RTK CAM-1 inhibits EGL-20/Wnt signaling in cell migration. Genetics 168, 1951-1962. Abstract Article

Gleason, J.E., and Eisenmann, D.M. (2010). Wnt signaling controls the stem cell-like asymmetric division of the epithelial seam cells during C. elegans larval development. Dev. Biol. 348, 58-66. Abstract Article

Gleason, J.E., Korswagen, H.C., and Eisenmann, D.M. (2002). Activation of Wnt signaling bypasses the requirement for RTK/Ras signaling during C. elegans vulval induction. Genes Dev. 16, 1281-1290. Abstract Article 
Gleason, J.E., Szyleyko, E.A., and Eisenmann, D.M. (2006). Multiple redundant Wnt signaling components function in two processes during C. elegans vulval development. Dev. Biol. 298, 442-457. Abstract Article

Glinka, A., Wu, W., Delius, H., Monaghan, A.P., Blumenstock, C., and Niehrs, C. (1998). Dickkopf-1 is a member of a new family of secreted proteins and functions in head induction. Nature 391, 357-362. Abstract Article

Goldstein, B., Takeshita, H., Mizumoto, K., and Sawa, H. (2006). Wnt signals can function as positional cues in establishing cell polarity. Dev. Cell 10,391-396. Abstract Article

Green, J.L., Inoue, T., and Sternberg, P.W. (2008). Opposing Wnt pathways orient cell polarity during organogenesis. Cell 134, 646-656. Abstract Article

Green, J.L., Kuntz, S.G., and Sternberg, P.W. (2008). Ror receptor tyrosine kinases: orphans no more. Trends Cell. Biol. 18, 536-544. Abstract Article

Guder, C., Philipp, I., Lengfeld, T., Watanabe, H., Hobmayer, B., and Holstein, T.W. (2006). The Wnt code: cnidarians signal the way. Oncogene 25, 7450-7460. Abstract Article

Gupta, B. P. et al. Morphogenesis of the vulva and the vulval-uterine connection (November 30, 2012), WormBook, ed. The C. elegans Research Community, WormBook, doi/10.1895/wormbook.1.152.1, http://www.wormbook.org.

Harris, J., Honigberg, L., Robinson, N., and Kenyon, C. (1996). Neuronal cell migration in C. elegans: regulation of Hox gene expression and cell position. Development 122, 3117-3131. Abstract

Harterink, M., Kim, D.H., Middelkoop, T.C., Doan, T.D., van Oudenaarden, A., and Korswagen, H.C. (2011). Neuroblast migration along the anteroposterior axis of $C$. elegans is controlled by opposing gradients of Wnts and a secreted Frizzled-related protein. Development 138, 2915-2924. Abstract

Harterink, M., Port, F., Lorenowicz, M.J., McGough, I.J., Silhankova, M., Betist, M.C., van Weering, J.R., van Heesbeen, R.G., Middelkoop, T.C., Basler, K., et al. (2011). A SNX3-dependent retromer pathway mediates retrograde transport of the Wnt sorting receptor Wntless and is required for Wnt secretion. Nat. Cell Biol. 13, 914-923. Abstract Article

Hawkins, N.C., Ellis, G.C., Bowerman, B., and Garriga, G. (2005). MOM-5 frizzled regulates the distribution of DSH-2 to control C. elegans asymmetric neuroblast divisions. Dev. Biol. 284, 246-259. Abstract Article

Hayashi, Y., Hirotsu, T., Iwata, R., Kage-Nakadai, E., Kunitomo, H., Ishihara, T., Iino, Y., and Kubo, T. (2009). A trophic role for Wnt-Ror kinase signaling during developmental pruning in Caenorhabditis elegans. Nat. Neurosci. 12, 981-987. Abstract Article

Hedgecock, E.M., Culotti, J.G., Hall, D.H., and Stern, B.D. (1987). Genetics of cell and axon migrations in Caenorhabditis elegans. Development 100, 365-382. Abstract

Herman, M.A. (2001). C. elegans POP-1/TCF functions in a canonical Wnt pathway that controls cell migration and in a noncanonical Wnt pathway that controls cell polarity. Development 128, 581-590. Abstract

Herman, M.A., and Horvitz, H.R. (1994). The Caenorhabditis elegans gene lin-44 controls the polarity of asymmetric cell divisions. Development 120, 1035-1047. Abstract

Herman, M.A., Vassilieva, L.L., Horvitz, H.R., Shaw, J.E., and Herman, R.K. (1995). The C. elegans gene lin-44, which controls the polarity of certain asymmetric cell divisions, encodes a Wnt protein and acts cell nonautonomously. Cell 83, 101-110. Abstract Article

Hilliard, M.A., and Bargmann, C.I. (2006). Wnt signals and frizzled activity orient anterior-posterior axon outgrowth in C. elegans. Dev. Cell 10,379-390. Abstract Article

Hoier, E.F., Mohler, W.A., Kim, S.K., and Hajnal, A. (2000). The Caenorhabditis elegans APC-related gene apr-1 is required for epithelial cell migration and Hox gene expression. Genes Dev. 14, 874-886. Abstract Article 
Hsieh, J.C., Kodjabachian, L., Rebbert, M.L., Rattner, A., Smallwood, P.M., Samos, C.H., Nusse, R., Dawid, I.B., and Nathans, J. (1999). A new secreted protein that binds to Wnt proteins and inhibits their activities. Nature 398, 431-436.) Abstract Article

Huang, S., Shetty, P., Robertson, S.M., and Lin, R. (2007). Binary cell fate specification during C. elegans embryogenesis driven by reiterated reciprocal asymmetry of TCF POP-1 and its coactivator $\beta$-catenin SYS- 1 . Development 134, 2685-2695. Abstract Article

Hunter, C.P., Harris, J.M., Maloof, J.N., and Kenyon, C. (1999). Hox gene expression in a single Caenorhabditis elegans cell is regulated by a caudal homolog and intercellular signals that inhibit wnt signaling. Development 126 , 805-814. Abstract

Inoue, T., Oz, H.S., Wiland, D., Gharib, S., Deshpande, R., Hill, R.J., Katz, W.S., and Sternberg, P.W. (2004). $C$. elegans LIN-18 is a Ryk ortholog and functions in parallel to LIN-17/Frizzled in Wnt signaling. Cell 118, 795-806. Abstract Article

Jensen, M., Hoerndli, F.J., Brockie, P.J., Wang, R., Johnson, E., Maxfield, D., Francis, M.M., Madsen, D.M., and Maricq, A.V. (2012). Wnt signaling regulates acetylcholine receptor translocation and synaptic plasticity in the adult nervous system. Cell 149, 173-187. Abstract Article

Jessen, J.R., Topczewski, J., Bingham, S., Sepich, D.S., Marlow, F., Chandrasekhar, A., and Solnica-Krezel, L. (2002). Zebrafish trilobite identifies new roles for Strabismus in gastrulation and neuronal movements. Nat. Cell Biol. 4, 610-615. Abstract Article

i N. and van Oudenaarden A. Single molecule fluorescent in situ hybridization (smFISH) of C. elegans worms and embryos (December 13, 2012), WormBook, ed. The C. elegans Research Community, WormBook, doi/10.1895/wormbook.1.153.1, http://www.wormbook.org.

Jiang, L.I., and Sternberg, P.W. (1998). Interactions of EGF, Wnt and HOM-C genes specify the P12 neuroectoblast fate in C. elegans. Development 125, 2337-2347. Abstract

Kaletta, T., Schnabel, H., and Schnabel, R. (1997). Binary specification of the embryonic lineage in Caenorhabditis elegans. Nature 390, 294-298. Abstract Article

Kennerdell, J.R., Fetter, R.D., and Bargmann, C.I. (2009). Wnt-Ror signaling to SIA and SIB neurons directs anterior axon guidance and nerve ring placement in C. elegans. Development 136, 3801-3810. Abstract Article

Kidd, A.R., 3rd, Miskowski, J.A., Siegfried, K.R., Sawa, H., and Kimble, J. (2005). A $\beta$-catenin identified by functional rather than sequence criteria and its role in Wnt/MAPK signaling. Cell 121, 761-772. Abstract Article

Kim, C., and Forrester, W.C. (2003). Functional analysis of the domains of the $C$ elegans Ror receptor tyrosine kinase CAM-1. Dev. Biol. 264, 376-390. Abstract Article

King, R.S., Maiden, S.L., Hawkins, N.C., Kidd, A.R., 3rd, Kimble, J., Hardin, J., and Walston, T.D. (2009). The Nor C-terminal domains of DSH-2 can activate the C. elegans Wnt/B-catenin asymmetry pathway. Dev. Biol. 328, 234-244. Abstract Article

Kirszenblat, L., Pattabiraman, D., and Hilliard, M.A. (2011). LIN-44/Wnt directs dendrite outgrowth through LIN-17/Frizzled in C. elegans neurons. PLoS Biol. 9, e1001157. Abstract Article

Klassen, M.P., and Shen, K. (2007). Wnt signaling positions neuromuscular connectivity by inhibiting synapse formation in C. elegans. Cell 130, 704-716. Abstract Article

Korswagen, H.C. (2002). Canonical and non-canonical Wnt signaling pathways in Caenorhabditis elegans: variations on a common signaling theme. Bioessays 24, 801-810. Abstract Article

Korswagen, H.C., Coudreuse, D.Y., Betist, M.C., van de Water, S., Zivkovic, D., and Clevers, H.C. (2002). The Axin-like protein PRY-1 is a negative regulator of a canonical Wnt pathway in C. elegans. Genes Dev. 16, 1291-1302. Abstract Article 
Korswagen, H.C., Herman, M.A., and Clevers, H.C. (2000). Distinct $\beta$-catenins mediate adhesion and signalling functions in C. elegans. Nature 406, 527-532. Abstract Article

Kusserow, A., Pang, K., Sturm, C., Hrouda, M., Lentfer, J., Schmidt, H.A., Technau, U., von Haeseler, A., Hobmayer, B., Martindale, M.Q., et al. (2005). Unexpected complexity of the Wnt gene family in a sea anemone. Nature 433, 156-160. Abstract Article

Lam, N., Chesney, M.A., and Kimble, J. (2006). Wnt signaling and CEH-22/tinman/Nkx2.5 specify a stem cell niche in C. elegans. Curr. Biol. 16, 287-295. Abstract Article

Lawrence, P.A., Struhl, G., and Casal, J. (2007). Planar cell polarity: one or two pathways? Nat. Rev. Genet. 8, 555-563. Abstract Article

Lin, R., Hill, R.J., and Priess, J.R. (1998). POP-1 and anterior-posterior fate decisions in C. elegans embryos. Cell 92, 229-239. Abstract Article

Lin, R., Thompson, S., and Priess, J.R. (1995). pop-1 encodes an HMG box protein required for the specification of a mesoderm precursor in early C. elegans embryos. Cell 83, 599-609. Abstract Article

Liu, J., Phillips, B.T., Amaya, M.F., Kimble, J., and Xu, W. (2008). The C. elegans SYS-1 protein is a bona fide $\beta$-catenin. Dev. Cell 14, 751-761. Abstract Article

Lo, M.C., Gay, F., Odom, R., Shi, Y., and Lin, R. (2004). Phosphorylation by the $\beta$-catenin/MAPK complex promotes 14-3-3-mediated nuclear export of TCF/POP-1 in signal-responsive cells in C. elegans. Cell 117, 95-106. Abstract Article

Lorenowicz, M.J., and Korswagen, H.C. (2009). Sailing with the Wnt: charting the Wnt processing and secretion route. Exp. Cell Res. 315, 2683-2689. Abstract Article

Lu, W., Yamamoto, V., Ortega, B., and Baltimore, D. (2004). Mammalian Ryk is a Wnt coreceptor required for stimulation of neurite outgrowth. Cell 119, 97-108. Abstract Article

Maduro, M.F., Lin, R., and Rothman, J.H. (2002). Dynamics of a developmental switch: recursive intracellular and intranuclear redistribution of Caenorhabditis elegans POP-1 parallels Wnt-inhibited transcriptional repression. Dev. Biol. 248, 128-142. Abstract Article

Maloof, J.N., Whangbo, J., Harris, J.M., Jongeward, G.D., and Kenyon, C. (1999). A Wnt signaling pathway controls hox gene expression and neuroblast migration in C. elegans. Development 126, 37-49. Abstract

Maro, G.S., Klassen, M.P., and Shen, K. (2009). A $\beta$-catenin-dependent Wnt pathway mediates anteroposterior axon guidance in C. elegans motor neurons. PLoS One 4, e4690. Abstract Article

Martin, B.L. and Kimelman, D. (2009) Wnt signaling and the evolution of embryonic posterior development. Curr. Biol. 19, R215-219 Abstract Article

Meneghini, M.D., Ishitani, T., Carter, J.C., Hisamoto, N., Ninomiya-Tsuji, J., Thorpe, C.J., Hamill, D.R., Matsumoto, K., and Bowerman, B. (1999). MAP kinase and Wnt pathways converge to downregulate an HMG-domain repressor in Caenorhabditis elegans. Nature 399, 793-797. Abstract Article

Mizumoto, K., and Sawa, H. (2007). Cortical $\beta$-catenin and APC regulate asymmetric nuclear $\beta$-catenin localization during asymmetric cell division in C. elegans. Dev. Cell 12, 287-299. Abstract Article

Mizumoto, K., and Sawa, H. (2007). Two ßs or not two ßs: regulation of asymmetric division by $\beta$-catenin. Trends Cell Biol. 17, 465-473. Abstract

Montcouquiol, M., Rachel, R.A., Lanford, P.J., Copeland, N.G., Jenkins, N.A., and Kelley, M.W. (2003). Identification of Vangl2 and Scrb1 as planar polarity genes in mammals. Nature 423, 173-177. Abstract Article 
Myers, T.R., and Greenwald, I. (2007). Wnt signal from multiple tissues and lin-3/EGF signal from the gonad maintain vulval precursor cell competence in Caenorhabditis elegans. Proc. Natl. Acad. Sci. U. S. A. 104, 20368-20373. Abstract Article

Najarro, E.H., Wong, L., Zhen, M., Carpio, E.P., Goncharov, A., Garriga, G., Lundquist, E.A., Jin, Y., and Ackley, B.D. (2012). Caenorhabditis elegans flamingo cadherin fmi-1 regulates GABAergic neuronal development. J. Neurosci. 32, 4196-4211. Abstract Article

Nakamura, K., Kim, S., Ishidate, T., Bei, Y., Pang, K., Shirayama, M., Trzepacz, C., Brownell, D.R., and Mello, C.C. (2005). Wnt signaling drives WRM-1/ß-catenin asymmetries in early C. elegans embryos. Genes Dev. 19, 1749-1754. Abstract Article

Natarajan, L., Witwer, N.E., and Eisenmann, D.M. (2001). The divergent Caenorhabditis elegans $\beta$-catenin proteins BAR-1, WRM-1 and HMP-2 make distinct protein interactions but retain functional redundancy in vivo. Genetics 159, 159-172. Abstract

Oosterveen, T., Coudreuse, D.Y., Yang, P.T., Fraser, E., Bergsma, J., Dale, T.C., and Korswagen, H.C. (2007). Two functionally distinct Axin-like proteins regulate canonical Wnt signaling in C. elegans. Dev. Biol. 308, 438-448. Abstract Article

Pan, C.L., Baum, P.D., Gu, M., Jorgensen, E.M., Clark, S.G., and Garriga, G. (2008). C. elegans AP-2 and retromer control Wnt signaling by regulating mig-14/Wntless. Dev. Cell 14, 132-139. Abstract Article

Pan, C.L., Howell, J.E., Clark, S.G., Hilliard, M., Cordes, S., Bargmann, C.I., and Garriga, G. (2006). Multiple Wnts and frizzled receptors regulate anteriorly directed cell and growth cone migrations in Caenorhabditis elegans. Deva. Cell 10, 367-377. Abstract Article

Park, F.D., and Priess, J.R. (2003). Establishment of POP-1 asymmetry in early C. elegans embryos. Development 130, 3547-3556. Abstract Article

Park, F.D., Tenlen, J.R., and Priess, J.R. (2004). C. elegans MOM-5/frizzled functions in MOM-2/Wnt-independent cell polarity and is localized asymmetrically prior to cell division. Curr. Biol. 14, 2252-2258. Abstract Article

Peters, J.M., McKay, R.M., McKay, J.P., and Graff, J.M. (1999). Casein kinase I transduces Wnt signals. Nature 401, 345-350. Abstract Article

Petersen, C.P., and Reddien, P.W. (2008). Smed-ßcatenin-1 is required for anteroposterior blastema polarity in planarian regeneration. Science 319, 327-330. Abstract

Petersen, C.P., and Reddien, P.W. (2009). Wnt signaling and the polarity of the primary body axis. Cell 139, 1056-1068. Abstract Article

Phillips, B.T., Kidd, A.R., 3rd, King, R., Hardin, J., and Kimble, J. (2007). Reciprocal asymmetry of SYS-1/ $\beta$-catenin and POP-1/TCF controls asymmetric divisions in Caenorhabditis elegans. Proc. Natl. Acad. Sci. U. S. A. 104, 3231-3236. Abstract Article

Port, F., and Basler, K. (2010). Wnt trafficking: new insights into Wnt maturation, secretion and spreading. Traffic 11, 1265-1271. Abstract Article

Port, F., Hausmann, G., and Basler, K. (2011). A genome-wide RNA interference screen uncovers two p24 proteins as regulators of Wingless secretion. EMBO Rep. 12, 1144-1152. Abstract Article

Port, F., Kuster, M., Herr, P., Furger, E., Banziger, C., Hausmann, G., and Basler, K. (2008). Wingless secretion promotes and requires retromer-dependent cycling of Wntless. Nat. Cell Biol. 10, 178-185. Abstract Article

Prasad, B.C., and Clark, S.G. (2006). Wnt signaling establishes anteroposterior neuronal polarity and requires retromer in C. elegans. Development 133, 1757-1766. Abstract Article 
Putzke, A.P., and Rothman, J.H. (2010). Repression of Wnt signaling by a Fer-type nonreceptor tyrosine kinase. Proc. Natl. Acad. Sci. U. S. A. 107, 16154-16159. Abstract Article

Raj, A., van den Bogaard, P., Rifkin, S.A., van Oudenaarden, A., and Tyagi, S. (2008). Imaging individual mRNA molecules using multiple singly labeled probes. Nat. Meth. 5, 877-879. Abstract Article

Robertson, S.M and Lin, R. (2012) Our evolving view of Wnt signaling in C. elegans: if two's company and three's a crowd, is four really necessary? Worm $1,82-89$. Article

Rocheleau, C.E., Downs, W.D., Lin, R., Wittmann, C., Bei, Y., Cha, Y.H., Ali, M., Priess, J.R., and Mello, C.C. (1997). Wnt signaling and an APC-related gene specify endoderm in early C. elegans embryos. Cell 90, 707-716. Abstract Article

Rocheleau, C.E., Yasuda, J., Shin, T.H., Lin, R., Sawa, H., Okano, H., Priess, J.R., Davis, R.J., and Mello, C.C. (1999). WRM-1 activates the LIT-1 protein kinase to transduce anterior/posterior polarity signals in C. elegans. Cell 97, 717-726. Abstract Article

Sanchez-Alvarez, L., Visanuvimol, J., McEwan, A., Su, A., Imai, J.H., and Colavita, A. (2011). VANG-1 and PRKL-1 cooperate to negatively regulate neurite formation in Caenorhabditis elegans. PLoS Genet. 7, e1002257. Abstract Article

Sawa, H., Kouike, H., and Okano, H. (2000). Components of the SWI/SNF complex are required for asymmetric cell division in C. elegans. Mol. Cell 6, 617-624. Abstract Article

Sawa, H., Lobel, L., and Horvitz, H.R. (1996). The Caenorhabditis elegans gene lin-17, which is required for certain asymmetric cell divisions, encodes a putative seven-transmembrane protein similar to the Drosophila frizzled protein. Genes Dev. 10, 2189-2197. Abstract Article

Schlesinger, A., Shelton, C.A., Maloof, J.N., Meneghini, M.D., and Bowerman, B. (1999). Wnt pathway components orient a mitotic spindle in the early Caenorhabditis elegans embryo without requiring gene transcription in the responding cell. Genes Dev. 13, 2028-2038. Abstract

Shetty, P., Lo, M.C., Robertson, S.M., and Lin, R. (2005). C. elegans TCF protein, POP-1, converts from repressor to activator as a result of Wnt-induced lowering of nuclear levels. Dev. Biol. 285, 584-592. Abstract Article

Shibata, Y., Takeshita, H., Sasakawa, N., and Sawa, H. (2010). Double bromodomain protein BET-1 and MYST HATs establish and maintain stable cell fates in C. elegans. Development 137, 1045-1053. Abstract Article

Shibata, Y., Uchida, M., Takeshita, H., Nishiwaki, K., and Sawa, H. (2012). Multiple functions of PBRM-1/Polybromo- and LET-526/Osa-containing chromatin remodeling complexes in C. elegans development. Dev. Biol. 361, 349-357. Abstract Article

Shin, T.H., Yasuda, J., Rocheleau, C.E., Lin, R., Soto, M., Bei, Y., Davis, R.J., and Mello, C.C. (1999). MOM-4, a MAP kinase kinase kinase-related protein, activates WRM-1/LIT-1 kinase to transduce anterior/posterior polarity signals in C. elegans. Mol. Cell 4, 275-280. Abstract Article

Shirayama, M., Soto, M.C., Ishidate, T., Kim, S., Nakamura, K., Bei, Y., van den Heuvel, S., and Mello, C.C. (2006). The conserved kinases CDK-1, GSK-3, KIN-19, and MBK-2 promote OMA-1 destruction to regulate the oocyte-to-embryo transition in C. elegans. Curr. Biol. 16, 47-55. Abstract Article

Siegfried, K.R., and Kimble, J. (2002). POP-1 controls axis formation during early gonadogenesis in C. elegans. Development 129, 443-453. Abstract

Silhankova, M., and Korswagen, H.C. (2007). Migration of neuronal cells along the anterior-posterior body axis of C. elegans: Wnts are in control. Curr. Opin. Genet. Dev. 17, 320-325. Abstract Article

Silhankova, M., Port, F., Harterink, M., Basler, K., and Korswagen, H.C. (2010). Wnt signalling requires MTM-6 and MTM-9 myotubularin lipid-phosphatase function in Wnt-producing cells. EMBO J. 29, 4094-4105. Abstract Article 
Song, S., Zhang, B., Sun, H., Li, X., Xiang, Y., Liu, Z., Huang, X., and Ding, M. (2010). A Wnt-Frz/Ror-Dsh pathway regulates neurite outgrowth in Caenorhabditis elegans. PLoS Genet. 6, e1001056. Abstract Article

Steimel, A., Wong, L., Najarro, E.H., Ackley, B.D., Garriga, G., and Hutter, H. (2010). The Flamingo ortholog FMI-1 controls pioneer-dependent navigation of follower axons in C. elegans. Development 137, 3663-3673. Abstract Article

Sternberg, P.W., Vulval development (June, 25 2005), WormBook, ed. The C. elegans Research Community, WormBook, doi/10.1895/wormbook.1.6.1, http://www.wormbook.org.

Sternberg, P.W., and Horvitz, H.R. (1988). lin-17 mutations of Caenorhabditis elegans disrupt certain asymmetric cell divisions. Dev. Biol. 130, 67-73. Abstract Article

Sugioka, K., Mizumoto, K., and Sawa, H. (2011). Wnt regulates spindle asymmetry to generate asymmetric nuclear $\beta$-catenin in C. elegans. Cell 146, 942-954. Abstract Article

Sulston, J.E., and Horvitz, H.R. (1977). Post-embryonic cell lineages of the nematode, Caenorhabditis elegans. Dev. Biol. 56, 110-156. Abstract Article

Sumiyoshi, E., Takahashi, S., Obata, H., Sugimoto, A., and Kohara, Y. (2011). The $\beta$-catenin HMP-2 functions downstream of Src in parallel with the Wnt pathway in early embryogenesis of C. elegans. Dev. Biol. 355, 302-312. Abstract Article

Takada, R., Satomi, Y., Kurata, T., Ueno, N., Norioka, S., Kondoh, H., Takao, T., and Takada, S. (2006). Monounsaturated fatty acid modification of Wnt protein: its role in Wnt secretion. Dev. Cell 11, 791-801. Abstract Article

Takeshita, H., and Sawa, H. (2005). Asymmetric cortical and nuclear localizations of WRM- $1 / \beta$-catenin during asymmetric cell division in C. elegans. Genes Dev. 19, 1743-1748. Abstract Article

Thorpe, C.J., Schlesinger, A., Carter, J.C., and Bowerman, B. (1997). Wnt signaling polarizes an early C. elegans blastomere to distinguish endoderm from mesoderm. Cell 90, 695-705. Abstract Article

Torban, E., Patenaude, A.M., Leclerc, S., Rakowiecki, S., Gauthier, S., Andelfinger, G., Epstein, D.J., and Gros, P. (2008). Genetic interaction between members of the Vangl family causes neural tube defects in mice. Proc. Natl. Acad. Sci. U. S. A. 105, 3449-3454. Abstract Article

Wallingford, J.B. (2012). Planar cell polarity and the developmental control of cell behavior in vertebrate embryos. Annu. Rev. Cell Dev. Biol. 28, 627-653. Abstract Article

Walston, T., Guo, C., Proenca, R., Wu, M., Herman, M., Hardin, J., and Hedgecock, E. (2006). mig-5/Dsh controls cell fate determination and cell migration in C. elegans. Dev. Biol. 298, 485-497. Abstract Article

Walston, T., Tuskey, C., Edgar, L., Hawkins, N., Ellis, G., Bowerman, B., Wood, W., and Hardin, J. (2004). Multiple Wnt signaling pathways converge to orient the mitotic spindle in early C. elegans embryos. Dev. Cell 7 , 831-841. Abstract Article

Walston, T.D., and Hardin, J. (2006). Wnt-dependent spindle polarization in the early C. elegans embryo. Semin. Cell Dev. Biol. 17, 204-213. Abstract Article

Whangbo, J., Harris, J., and Kenyon, C. (2000). Multiple levels of regulation specify the polarity of an asymmetric cell division in C. elegans. Development 127, 4587-4598. Abstract

Whangbo, J., and Kenyon, C. (1999). A Wnt signaling system that specifies two patterns of cell migration in $C$. elegans. Mol. Cell 4, 851-858. Abstract Article

Wildwater, M., Sander, N., de Vreede, G., and van den Heuvel, S. (2011). Cell shape and Wnt signaling redundantly control the division axis of C. elegans epithelial stem cells. Development 138, 4375-4385. Abstract Article 
Willert, K., Brown, J.D., Danenberg, E., Duncan, A.W., Weissman, I.L., Reya, T., Yates, J.R., 3rd, and Nusse, R. (2003). Wnt proteins are lipid-modified and can act as stem cell growth factors. Nature 423, 448-452. Abstract Article

Wong, H.C., Bourdelas, A., Krauss, A., Lee, H.J., Shao, Y., Wu, D., Mlodzik, M., Shi, D.L., and Zheng, J. (2003). Direct binding of the PDZ domain of Dishevelled to a conserved internal sequence in the C-terminal region of Frizzled. Mol. Cell 12, 1251-1260. Abstract Article

Wu, J., and Mlodzik, M. (2009). A quest for the mechanism regulating global planar cell polarity of tissues. Trends Cell Biol. 19, 295-305. Abstract Article

Wu, M., and Herman, M.A. (2006). A novel noncanonical Wnt pathway is involved in the regulation of the asymmetric B cell division in C. elegans. Dev. Biol. 293, 316-329. Abstract Article

Xu, Y.K., and Nusse, R. (1998). The Frizzled CRD domain is conserved in diverse proteins including several receptor tyrosine kinases. Curr. Biol. 8, R405-406. Abstract

Yamamoto, Y., Takeshita, H., and Sawa, H. (2011). Multiple Wnts redundantly control polarity orientation in Caenorhabditis elegans epithelial stem cells. PLoS Genet. 7, e1002308. Abstract Article

Yang, P.T., Lorenowicz, M.J., Silhankova, M., Coudreuse, D.Y., Betist, M.C., and Korswagen, H.C. (2008). Wnt signaling requires retromer-dependent recycling of MIG-14/Wntless in Wnt-producing cells. Dev. Cell 14, 140-147. Abstract Article

Yang, X.D., Huang, S., Lo, M.C., Mizumoto, K., Sawa, H., Xu, W., Robertson, S., and Lin, R. (2011). Distinct and mutually inhibitory binding by two divergent $\beta$-catenins coordinates TCF levels and activity in $C$. elegans. Development 138, 4255-4265. Abstract Article

Yoda, A., Kouike, H., Okano, H., and Sawa, H. (2005). Components of the transcriptional Mediator complex are required for asymmetric cell division in C. elegans. Development 132, 1885-1893. Abstract Article

Yoshikawa, S., McKinnon, R.D., Kokel, M., and Thomas, J.B. (2003). Wnt-mediated axon guidance via the Drosophila Derailed receptor. Nature 422, 583-588. Abstract Article

Zecca, M., Basler, K., and Struhl, G. (1996). Direct and long-range action of a wingless morphogen gradient. Cell 87, 833-844. Abstract Article

Zhang, H., and Emmons, S.W. (2000). A C. elegans mediator protein confers regulatory selectivity on lineage-specific expression of a transcription factor gene. Genes Dev. 14, 2161-2172. Abstract Article

Zhao, X., Yang, Y., Fitch, D.H.A., and Herman, M.A. (2002). TLP-1 is an asymmetric cell fate determinant that responds to Wnt signals and controls male tail tip morphogenesis in C. elegans. Development 129, 1497-1508. Abstract

Zinovyeva, A.Y., and Forrester, W.C. (2005). The C. elegans Frizzled CFZ-2 is required for cell migration and interacts with multiple Wnt signaling pathways. Dev. Biol. 285, 447-461. Abstract Article

Zinovyeva, A.Y., Yamamoto, Y., Sawa, H., and Forrester, W.C. (2008). Complex network of Wnt signaling regulates neuronal migrations during Caenorhabditis elegans development. Genetics 179, 1357-1371. Abstract Article

All WormBook content, except where otherwise noted, is licensed under a Creative Commons Attribution License. 